\title{
THE "NEW" FEDERAL TRADE COMMISSION AND THE ENFORCEMENT OF THE ANTITRUST LAWS
}

\author{
I have given you my Law, and you set up commissions. \\ Eliot, "The Rock"
}

The Federal Trade Commission is a quasi-judicial administrative agency whose jurisdiction extends to the prevention of all "unfair methods of competition" carried on in interstate commerce and to the enforcement of the antitrust laws of the United States. ${ }^{1}$ The judiciary, after initial mistrust, now generally defers to the Commission's economic "expertise."2 Yet the FTC has been criticized for enforcing the antitrust laws overzealously; ${ }^{3}$ for not enforcing the antitrust laws zealously enough ; and for failing to assist businessmen to understand and comply with those laws. ${ }^{5}$

1. Section 5 of the Federal Trade Commission Act proscribes all "unfair methods of competition." 38 STAT. 719 (1914), as amended, 15 U.S.C. § 45(a) (1952). The phraseology was intentionally set beyond precise definition in order to permit the expansibility that changing conditions would require. FTC v. Cement Institute, 333 U.S. 683, 708 (1948) ; FTC v. Raladam, 283 U.S. 643, 648 (1931). It gave the FTC "adequate power to hit at every trade practice, then existing or thereafter contrived, which restrained competition. ..." FTC v. Cement Institute, supra at 693. See also United States v. Morton Salt Co., 338 U.S. 632 (1950).

The FTC Act was intended to prevent, in their incipiency, methods of doing business which might restrain trade. Fashion Originators' Guild, Inc. v. FTC, 312 U.S. 457, 460 (1941) ; FTC v. Raladam, supra at 647. It thereby empowers the Commission to prevent potential violations of the Sherman Act, 26 STAт. 209 (1890), 15 U.S.C. \& 1 (1952), and of the Clayton Act, 38 STAT. 730 (1914), as amended, 15 U.S.C. $\$ 12$ (1952). See FTC v. Motion Picture Advertising Serv. Co., 344 U.S. 392, 394 (1953) ; FTC v. Beech-Nut Packing Co., 257 U.S. 441, 453 (1922). Section 11 of the Clayton Act separately empowers the Commission to enforce $\$ \$ 2,3,7$ and 8 of that Act. 38 Stat. 734 (1914), 15 U.S.C. $\$ 21$ (1952). See note 25 infra.

2. E.g., compare FTC v. Ruberoid Co., 343 U.S. 470 (1952), with FTC v. Gratz, 253 U.S. 421 (1920). "Congress having now created an organ endued with the skill which comes of long experience and penetrating study, its conclusions inevitably supersede those of the courts, which are not similarly endowed." L. Hand, J., in Herzfeld v. FTC, 140 F.2d 207, 209 (2d Cir. 1944). But, for an excellent discussion debunking the myth of administrative "expertise," see Schwartz, Legal Restriction of Competition in Regulated Industries: An Abdication of Judicial Responsibility, 67 HARv. L. REv. 436, 471-75 (1954).

3. See, e.g., Dirladi \& Kann, Fair Coapetition: The Law and Econonics of Antitrust Policy 188 (1954); Ferguson, Recomnendations From Congress-A Congressional Viewooint on Current Antitrist Problems, 5 Hastings L.J. 59, 62-64, 67 (1953) ; Simon, The Case Against the Federal Trade Commission, 19 U. CHI. L. REv. 297 (1952). But see Wallace \& Douglas, Antitrust Policies and the New Attack an the Federal Trade Commission, 19 U. CEr. L. REv. 684 (1952).

4. See, e.g., H.R. Rep. No. 3236, 81st Cong., 2d Sess. 16-21 (1951) (Patman Small Business Committee) ; charges of Senator Patman, N.Y. Times, May 11, 1955, p. 20, col. 3; 
In March 1953, a new Chairman was appointed to the FTC. ${ }^{6}$ Since that time, significant shifts in the antitrust outlook of the Commission have become discernible. ${ }^{7}$ Some of these shifts had their roots before $1953 ;^{8}$ others reflect more directly the influence of a new majority and a new Chairman. ${ }^{9}$ These shifts in the composition, the outlook and the activities of the Commission mark the directions of the "new" FTC.

In general, the directions of the "new" FTC promise to bring it more closely into line with the functions and significance Congress originally envisaged for it as an expert, preventive agency. ${ }^{10}$ The Commission will stress

Jan. 2, 1953, p. 12, col. 6; charges of Senator Kefauver, id., June 13, 1955, p. 33, col. 4; Feb. 20, 1955, p. 2, col. 4; Jan. 27, 1955, p. 21, col. 1 ; charges of the International Business Federation, id., Aug. 30, 1954, p. 22, col. 4; Aug. 31, 1953, p. 23, col. 2; April 29, 1955, p. 11, col. 2. But see Kintner, The Revitalized Federal Trade Commission: A Two-Year Eraluation, 30 N.Y.U.L. REv. 1143 (1955).

5. See, e.g., S. REP. No. 2627, 81st Cong., 2d Sess. 5 (1950) ; S. Doc. No. 27, 81st Cong., 1st Sess. (1949). The orders of the old Commission have been sharply attacked for their vague generality. See Report of tHe AtToRney General's Natronal CoMamitee to Study the Antimeust Laws 167 (1955) (hereinafter cited as Atr'y GeN. Comm. Rep.) ; Effective Competition, Report to the Secretary of Commerce by his Business Advisory Conncil 1 (1952) (hereinafter cited as Effective Competition) ; FTC v. Motion Picture Advertising Serv. Co., 344 U.S. 392, 398 (1953) (dissent); FTC v. Kuberoid Co., 343 U.S. 470, 492-93 (1952) (dissent).

6. Edward F. Howrey was appointed Chairman of the FTC in March 1953. This appointment created a Republican majority. See Repnblicans Reshape FTC, Business Week, Jan. 5, 1954, p. 53; Softening Up the FTC, The Nation, April 4, 1953, p. 277; cf. Kintner, supra note 4, at 1147. Chairman Howrey resigned in August 1955, N.Y. Times, Aug. 11, 1955, p. \&, col. 4, and was succeeded by Commissioner John W. Gwynne. See Time, Aug. 22, 1955, p. 73. Chairman Howrey's importance as spokesman and architect of the "new" FTC scarcely can be overestimated. But the fundamental orientation of the "new" Commission is unlikely to be disturbed so long as a Republican majority maintains control. See ibid; cf. 2 CCH Trade Reg. Rep. I 8506 (1954).

7. See, c.g., New Look Coning in Antitrust, Business Week, July 7, 1953, p. 29; Businesslike Antitrust Policy, Fortune, Nov. 1953, p. 115; United States and Business: Era of Good Fecling?, U.S. News, July 24, 1953, p. 69. See also Sunderland, Antitrust Developments During the Past Year, 36 CHI. BAR RecoRD 103 (1954).

8 . The use of consensual and educational techniques to prevent antitrust violations, now strongly stressed by the "new" Commission, see notes 30-61 infra and accompanying text, was pioneered by "old" Commissions. See Comment, 62 YaLE L.J. 912, 915 (1952); FTC ANN. Rep. 77 (1952); 16 C.F.R. § 1.3(d) (1949).

9. See, $e . g$. notes 10-13 infra and accompanying text. One critic has questioned how a change in basic policy due to a change in political membership squares with the theory of administrative "expertise." See Schwartz, supra note 2, at 471-75. See also Clark, C.J., dissenting in Rosenblum v. FTC, 214 F.2d 338, 339-40 (2d Cir. 1954).

10. See S. Rep. No. 597, 63d Cong., 2d Sess. passim (1914) ; FTC v. Keppel \& Bros., 291 U.S. 304, 314 (1934) ; Atr'y Gen. Consm. Rep. 132.

"In creating the Federal Trade Commission, Congress had two principal ideas in mind: first, to create a 'body of experts' competent to deal with complex competitive practices by reason of information, experience and careful study of business and economic conditions'; and second, to authorize this body of experts to deal with unfair competitive methods in their incipient stages." FTC ANr. REP. 1 (1954); Address by Howrey, Re- 
the use of voluntary rather than adversary procedures to secure compliance with the antitrust laws. ${ }^{11}$ It will try to reserve its adversary procedures for "hard-core" violations. ${ }^{12}$ And in applying the law the Commission will strive for an "expert" flexibility : per se presumptions will be used sparingly, and the scope of inquiry into the market effects of competitive practices will tend to be as wide as the market forces involved. ${ }^{13}$ However, some procedural and many substantive developments under the "new" FTC warrant sharp criticism or qualification. In particular, unless the "new" FTC distinguishes more carefully than it has between the scope of the inquiry and the amount of evidence necessary to establish a prima facie case, it is likely to hamper antitrust enforcement by establishing a burden of proof substantially greater than that required by the antitrust laws. ${ }^{14}$

valuation of the Commission's Responsibilities, June 18, 1953, at 2; see also Address by Howrey, A Report of Progress, Aug. 19, 1954, at 1.

11. See notes 32-47 infra and accompanying text.

12. The "new" FTC will try to reserve its adversary procedures for hard-core violations of the law, rather than to decide "test" cases of minor economic significance. See FTC ANN. Rep. 3 (1954) ; Howrey, Report of Progress, supra note 10, at 5; Howrey, Statement Before the Subcommittee on Antitrust and Monopoly of the Senate Committee on the Judiciary 3 (1955) (mimeograph) ; Howrey, Statement Before the House of Representatives Committee on Small Business 3 (1.954) (mimeograph). But see the charge of the National Federation of Independent Business that the FTC is concentrating on insignificant price discrimination cases while ignoring the more important ones. N.Y. Times, Aug. 30, 1954, p. 22, col. 4.

If by this statement the Commission means that it will try to settle cases involving unintentional violations of the law whenever it is convinced that respondents will discontinue the challenged practices, its stress on "hard-core" prosecutions seems to be desirable. If, however, the Commission means that it will shy away from prosecuting prevalent market practices because they never have been declared illegal in the past, its policy would conflict with the policy Congress expressed in creating an "expert" agency that is able to proscribe new forms of anti-competitive practices as they materialize. See notes 1, 10 supra. This Comment interprets the Commission's statements to indicate that cases will be chosen on the basis of market significance rather than ideological novelty, but not that only intentional violations of previously-known offenses will be prosecuted. But see Loescher, Inert Antitrust Administration: Formula Pricing and the Cement Industry, 65 YALE L.J. 1 (1955).

13. See text at notes 66-75 infra; FTC ANN. Rep. 2 (1954).

In order to implement this policy, the FTC has revitalized the Bureau of Economics. See $i d$. at 21-23; Howrey, Report of Progress, supra note 10, at 3; Address by Howrey, Economic Evidence in Antitrust Cases, June 1954, at 3, 5. "The acquisition of information is an essential prerequisite to both intelligent regulation and the recommendation of additional legislation." MacChesney, Investigatory and Enforcement Powers of the Federal Trade Commission, 8 Geo. WasH. L. REv. 581, 582 (1940); see also Stevens, The Federal Trade Connnission's Contribution to Industrial and Economic Analysis: The Work of the Economic Division, $8 \mathrm{id}$. at 545, 563-68. The new stress upon gathering economic information and integrating it with antitrust policy is a welcome sign that the "expert" agency is anxious to prove its expertise.

14. See pp. 45-81 infra. For a discussion of whether the Commission should be permitted to do so, and suggestions as to possible curbs, see pp. $81-85$ infra. 
Formal Procedure of the "New" FTC

The FTC operates under the Federal Trade Commission Act, the Administrative Procedure Act and its own Rules of Practice. ${ }^{15}$ Adversary hearings are conducted against named persons charged with specific violations of the antitrust laws. ${ }^{10}$ They are conducted by a Hearing Examiner who exercises powers comparable to those of a trial judge. ${ }^{17}$ After hearings close the examiner prepares an initial decision, ruling on all justiciable issues, which becomes final unless it is seasonably brought for review to the FTC. ${ }^{18}$

When the FTC does review an initial decision, it is free to exercise all the powers it would have exercised if it had heard the case de novo. ${ }^{19}$ This in-

15. The FTC has thirty-one Rules of Practice, see 16 C.F.R. $\$ 2.1$ et seq. (1949), 15 U.S.C. pp. 1626-36 (1952). It must also conform to the Administrative Procedure Act, 60 Stat. 237 (1946), as amended, 5 U.S.C. $\$ 1001$ (1952), and the FTC Act, 38 Stat. 717 (1914), as amended, 15 U.S.C. $\$ 41$ (1952).

16. See Rule of Practice 5(a), 16 C.F.R. $\$ 2.5$ (a) (1949). The proceedings are generally governed by rule $15,16 \mathrm{id}$. 2.15 .

The FTC may institute proceedings entirely on its own initiative, see United States v. Morton Salt Co., 338 U.S. 632, 642 (1950), or in response to an application by competing businessmen alleging violations of the law. Rule of Practice 4, 16 C.F.R. $\$ 2.4$ (1949). About $65 \%$ of all cases originate outside the FTC. Freer, Federal Trade Commission Procedure and Practice, 8 Geo. WasH. L. Rev. 316, 317 (1940). The complaining businessman is not a party to the FTC action, however; the Commission acts "ex parte and only where substantial public interest is involved." Freer, Practice Before the FTC, 7 Geo. WaSH. L. Rev. 283, 285 (1939); see 16 C.F.R. $\$ 1.1$ (1949). The complaining businessman may be permitted to intervene on written motion as an "interested person." See $16 \mathrm{id}$. $\$ 2.9$. It is also possible that he may be permitted to appeal from a decision adverse to his interests. See notes 296-302 infra and accompanying text.

17. "To assure a proper functioning of the Commission as a quasi-judicial agency, a number of steps have been taken to increase the authority of the hearing examiners who, as triers of fact, are of key importance in the administrative process." Howrey, $A$ Report of Progress, supra note 10, at 5 . He is empowered to regulate the course of the hearings, to rule on offers of proof, and to take "any other action authorized by Commission rule consistent with the Administrative Procedure Act." Rule of Practice 14, 16 C.F.R. § 2.14 (1949).

Under new Rule of Practice 10, 16 id. $\S 2.10$, the examiner now may dismiss an FTC complaint for failure to state a valid cause of action, and for lack of public interest. See Premier Pillow Co., Docket No. 6136, 3 CCH Trade Reg. Rep. I 25276 (FTC Dec. 1954); but cf. Florida Citrus Mutual Co., Docket No. 6074, 3 id. \{ 25076 (FTC March 1954). Interviews with Commissioners and Staff members in March 1955 (hereinafter cited as INTERVIEWS), indicate that the power and prestige of the examiner will be enhanced still further until he is able to exercise the function of a trial judge. See also Address by Howrey, FTC Decisions, April 2, 1954, at 7.

18. The initial decision becomes official after thirty days unless one of the parties appeals to the Commission or the Commission moves to review the decision on its own initiative. Rules of Practice 22, 23, 16 C.F.R. \$\$ 2.22, 2.23 (1949). The "new" FTC will, whenever possible, adopt the examiner's decisions rather than ignore them and make its own findings de novo. FTC AnN. ReP. 3 (1954); InTERviews; Howrey, $A$ Report of Progress, supra note 10, at 4 .

19. Administrative Procedure Act, 60 Stat. 242 (1946), 5 U.S.C. $\S 1007$ (a); Rules of Practice 22(a), 25(a), 16 C.F.R. \$ 2.22(a), 2.25(a) (1949). 
cludes the power to make original findings of fact. ${ }^{20}$ If the FTC finds that respondent violated the law, it issues an order enjoining the illegal practices. ${ }^{21}$ Respondent may appeal such an order to the appellate courts. ${ }^{22}$ FTC counsel may not appeal an order exonerating the respondent. ${ }^{23}$

The FTC could lubricate the channels of enforcement if it phrased Clayton Act orders under both the Clayton Act and the FTC Act. Orders issued under section 5 of the FTC Act are immediately operative in their own right:24 orders issued only under section 11 of the Clayton Act do not become opera-

20. See note 19 supra.

"The power to determine facts is probably as great a power, if not greater, than the power to interpret the law." Address by Howrey, FTC \& The Administrative Process, Jan. 28, 1954, at 11. "The facts of a case, remember, are not what actually happened but, at best, what the trial court says it thinks happened." FRANK, CoURTS ON TRIAL 326 (1950). This is especially true in the case of the FTC because of the immense deference courts pay to its "expertise" in "finding" the "facts." So long as there is evidence in the record supporting the Commission's findings, the courts do not quarrel with the conclusions the FTC draws. FTC v. Standard Educational Society, 302 U.S. 112, 117 (1937) ; FTC v. Algoma Lumber Co., 291 U.S. 67, 73 (1934), See note 2 supra.

21. "Orders of the Federal Trade Commission are not intended to impose criminal punishment or exact compensatory damages for past acts, but to prevent illegal practices in the future. In carrying out this function the Commission is not limited to prohibiting the illegal practice in the precise form in which it is found to have existed in the past.... it must be allowed effectively to close all roads to the prohibited goal. . ." FTC v. Ruberoid Co., 343 U.S. 470, 473 (1952) ; see also FTC v. Morton Salt Co., 334 U.S. 37, 51-52 (1948); FTC v. Cement Institute, 333 U.S. 683, 708 (1948).

In the past, FTC orders were overly broad. See note 5 supra. Also, the "old" FTC seldom wrote opinions in cases it lost. Freer, Federal Trade Commission Procedure and Practice, 8 Geo. WASH. L. Rev. 316, 333 (1940); cf. Kintner, supra note 4, at 1152. The "new" Commission is remedying this situation. "It is important that the business world know what it may do, as well as what it may not do." Howrey, FTC Decisions, supra note 17 , at 2 . "It is my hope that ... future published decisions will not only constitute the authentic public record of what was done in a particular case but will also afford a collection of precedents by which its handling of future cases can be forecasted. ..." FTC AnN. Rep. 3 (1954). Howrey, Report of Progress, supra note 10, at 4. Furthermore, recent decisions seem far more readable and informative than the formalistic orders of the "old" FTC.

22. 38 STAT. 720 (1914), 15 U.S.C. \& 45(c) (1952). However, the courts will not disturb the Commission remedy unless it has "no reasonable relation to the unlawful practices found to exist." Siegal v, FTC, 327 U.S. 608, 613 (1946) ; see FTC v. Ruberoid Co., 343 U.S. 470,473 (1952).

23. "If this Commission wrongs a corporation, the corporation can appeal to the courts for relief. If this Commission wrongs the public ... there is no appeal by the public to the courts." Alabama Metal \& Lath Co., Docket No. 5449, 3 CCH Trade REg. Rep. \ 11644 (FTC Feb. 1954) (Mead dissenting). See also 2 id. II 8621 (1954); Note, 55 Colum. L. Rev. 561, 565 (1955). But see notes 296-302 infra and accompanying text.

24. 52 Stat. 114 (1938) (Wheeler-Lea Amendment), 15 U.S.C. $\S 45(\mathrm{~g})$ (1952), amending 38 STAT. 721 (1914). FTC orders are now "finalized" by the passage of sixty days, unless they are appealed. Ibid. Thereafter, any violation of the order is, per se, punishable by civil penalties of $\$ 5,000$ per day. Ibid; see Comment, 62 YALE L.J. 912,914 n.21 (1952) ; 2 CCH TRADE REg. ReP. $\llbracket 17215$ (1954); 16 C.F.R. $\$ 7.5$ (1949). 
tive until the FTC obtains a judicial order of enforcement. ${ }^{25}$ Any practice that violates the Clayton Act is also an "unfair method of competition" under the FTC Act." However, the "new" FTC is unwilling to accept the advantages of immediate enforceability that are inherent in an FTC Act order; it seems to feel that its function is to "warn" rather than "punish."27 But policy considerations indicate that all orders should be self-executing to the full limit of the laws. ${ }^{28}$ This curious preference for the less efficient alternative is probably the only procedural innovation attributable to the "new" FTC that warrants adverse comment. ${ }^{20}$

\section{Voluntary and Informal Procedures of the "New" FTC}

The "new" Commission will try to get compliance with the antitrust laws without the use of extended litigation. It will try to avoid litigation by making

25. 38 STAT. 734 (1914), 15 U.S.C. $\$ 21$ (1952). After issuing an order under $\S 11$, the FTC must show that a violation of the order has occurred or is imminent before it can get a judicial order of enforcement. And fines issue against a respondent only if he violates the court's orders; no penalties are incurred by violating the Commission's order, as such. See FTC v. Ruberoid Co., 343 U.S. $470,478-79$ (1952); FTC v. Standard Brands, Inc., $189 \mathrm{~F} .2 \mathrm{~d} 510$ (2d Cir. 1951). The respondent is thus entitled to one more free bite than the common-law dog.

26. E.g., FTC v. Motion Picture Advertising Serv. Co., 344 U.S. 392, 394 (1.953) (Sherman Act or Clayton Act) ; Fashion Originators' Guild, Inc. v. FTC, 312 U.S. 457, 466 (1941) (Sherman Act) ; Hershey Chocolate Corp. v. FTC, 121 F.2d 968, 970-71 (3d Cir. 1941) (Clayton Act).

27. The FTC can and has achieved immediate enforceability of orders prohibiting Clayton Act offenses by issuing the orders under both the Clayton Act and the FTC Act. See Motion Picture Advertising Serv. Co., 47 F.T.C. 378 (1950), aff'd, 344 U.S. 392 (1953) ; Dictograph Products, Inc., Docket No. 5655 (FTC Sept. 1953), aff'd, 217 F.2d 821 (2d Cir. 1954).

However, in Harley Davidson Motor Co., Docket No. 5968, 3 CCH Trade Reg. Rep. If 2510 S (FTC June 1954), the "new" FTC expressly chose to find a violation only under $\S 3$ of the Clayton Act (although the examiner had found a violation of the Clayton Act and the FTC Act). The Commission seemed to feel that its function was only to "warn," not "penalize." See $i d$. at 35256. InTERvIEws indicate that, short of legislative amendment, the "new" Commission will not bring future actions under $\S 5$ if they will fit under the more specific proscriptions of the Clayton Act.

28. United States Steel Corp., Docket No. 760, CCH Trade Reg. Rep. If 14081 (FTC Oct. 1948), illustrates the weakness of Clayton Act orders. An order was issued against respondent in 1924 under the FTC Act, which was then equivalent to the Clayton Act. Respondent did nothing about it. Only in 1938, when the Wheeler-Lea Amendment put teeth into FTC orders, see note 24 supra, did respondent bother to appeal.

Legislative amendment of $\S 11$ to square it with $\S 5$ of the FTC Act has been proposed by Senator Sparkman, Chairman of the Senate Small Business Committee. S. 2205, 84th Cong., 1st Sess. (1955). See N.Y. Times, June 13, 1955, p. 33, col. 4. Similar legislation has been proposed by the Attorney General's National Committee to Study the Antitrust Laws, Atr'y Gen. Comm. Rep. 373, and by the "old" FTC, FTC Ann. Rep. 3 (1952). See FTC v. Ruberoid Co., 343 U.S. 470,479 (1952).

29. Kintner, supra note 4, at 1148-52, surveys several other excellent innovations by which the "new" Commission has streamlined its internal procedures. 
greater use of consent orders and informal stipulations, ${ }^{30}$ and by establishing standards that will make it easier for businessmen to stay within the laws. ${ }^{31}$

The use of consent orders to cease and desist has been broadly extended.32 Consent orders may now be issued at any stage of FTC proceedings, and they may cover only some of the parties and some of the issues. ${ }^{33}$ Findings of fact need not be made; respondent may expressly stipulate that consent to the order does not admit the truth of the charges made. ${ }^{34}$ However, he must agree that the order will have the same force and effect as if it were entered after a full hearing. ${ }^{35}$ And he must agree that the complaint may be used to construe the order. ${ }^{36}$

The "new" Commission will also make greater use of informal stipulations of fact and informal promises to discontinue challenged practices. ${ }^{37}$ Certainly, if informal settlements promise to terminate illegal practices as effectively as formal orders, the costly litigation that may be necessary to obtain a formal order is not in the public interest. ${ }^{38}$ The use of settlement procedures is, of course, wholly discretionary: it is limited to instances in which a respondent

30. See notes $32-40$ infra and accompanying text.

31. See notes 41-61 infra and accompanying text.

32. See FTC Rule of Practice 5(c), 16 C.F.R. $\$ 2.5$ (c) (Supp. 1954). See also FTC ANn. REP. 6 (1954); Howrey, Report of Progress, supra note 10, at 9.

33. See authorities cited note 32 supra.

34. "Under the new rule, the only admission required of respondents is that of jurisdiction." Howrey, Report of Progress, supra note 10, at 7. See authorities cited note 32 supra.

35. Ibid. Of course, consent orders are enforceable in the courts just as any other order, even without any findings of fact. See NLRB v. J. L. Hudson Co., 135 F.2d 380 (6th Cir.), cert. denied, 320 U.S. 740 (1943). And any error of fact that is stated is "waived by consent to the decree." Swift \& Co. v. United States, 276 U.S. 311 (1927); of. National Candy Co. v. FTC, 104 F.2d 999 (7th Cir.), cert. denied, 30S U.S. 610 (1939); Kintner, supra note 4, at 1153 .

36. See authorities cited note 32 supra.

37. See Wildroot Co., 49 F.T.C. 1578 (1953) ; Howrey, Revahuation, supra note 10, at 6. If the FTC is persuaded that it is in the public interest to accept an informal promise to cease and desist, it can either decide not to issue a formal complaint or withdraw one that has already been issued. But the stipulation itself is a matter of public record. 16 C.F.R. $\S 1.3$ (c) (1949). And it is not a bar to subsequent action if the Commission feels it was in error: "[I]t is unthinkable that the public interest should be allowed to suffer as a result of inadvertence or mistake on the part of the Commission or its counsel. . . " P. Lorillard Co. v. FTC, 186 F.2d 52, 55 (4th Cir. 1950) ; cf. Rock v. FTC, 117 F.2d 680 (7th Cir. 1941).

Of course, the use of stipulations is not new with the "new" Commission. It was also the policy of the "old" Commission to utilize stipulation procedures to "avoid the need for adversary proceedings against persons who . . violate the law unintentionally." 16 C.F.R. $\S 1.3$ (d) (1949). The change is a matter of stress. See the "new" Commission's Wildroot Co. case, supra.

38. See Sugar Institute, Inc. v. United States, 297 U.S. 553, 598 (1936) ; Eugene Dietzgen Co. v. FTC, 142 F.2d 321, 330 (7th Cir. 1944); Howrey, Revaluation, supra note 10, at 6: "If, however, the action of the wrongdoer does not insure cessation, ... an order to cease and desist is appropriate." 
affirmatively convinces the Commission that he will not resume the challenged practices. $^{30}$ It is usually unavailable to respondents charged with Sherman or Clayton Act violations. ${ }^{40}$

The FTC is trying to adapt Trade Practice Conference Rules to antitrust problems in the hope that it may discourage borderline violations of the law by making the law clearer to businessmen. ${ }^{41}$ At semi-formal conferences FTC counsel help members of an industry to draft Trade Rules which are oriented to and expressed in the language of the particular industry. ${ }^{42}$ These Rules are not substantive law, and they cannot be enforced as if they were; they are in the nature of advisory opinions. ${ }^{43}$ But if a businessman wants to obey the law, the Rules present it to him in the terms of his trade. ${ }^{44}$ If he wants to violate the law, the Rules make it easier for the FTC to find that

39. See Consolidated Royal Chemical Corp. v. FTC, 191 F.2d 896, 898 (7th Cir. 1951); Galter v. FTC, 186 F.2d 810, 812 (7th Cir. 1951). See also FTC statement of policy, 16 C.F.R. $\S 1.3$ (d) (1949).

40. "Conspiracies and monopolistic practices are, with few exceptions, deliberately engaged in ... with knowledge of their illegality. Since good faith is ordinarily lacking in such violations, it cannot be expected to be present in agreements by the conspirators to discontinue and not resume the violations." $16 \mathrm{id} . \$ 1.3(\mathrm{~h})$; see also United States Steel Corp., Docket No. 6078, 3 CCH Trade Reg. Rep. If 25393 (FTC March 28, 1955). But see Wildroot Co., 49 F.T.C. 1578, 1581-82 (1953).

41. FTC Rule of Practice 28 provides for Trade Practice Conferences to give businessmen an opportunity "for voluntary participation by industrial groups . . . in the formulation of rules to provide for elimination or prevention of unfair methods of competition ... and other illegal trade practices." 16 C.F.R. $\S 2.28$ (a) (1949). For an excellent study of the Rules under the "old" Commission (primarily directed at advertising aspects), see Comment, 62 Yale L.J. 912 (1953) ; see also Kittelle \& Mostow, $A$ Review of the Trade Practice Conferences of the Federal Trade Commission, 8 Geo. WAsh. L. Rev. 427 (1940).

42. The FTC may authorize Conferences on its own motion or upon the application of industry members. Proceedings consist of informal discussions with FTC staff members followed by discussions among the industry's members conducted by the FTC. See 16 C.F.R. $\$ \$ 2.28$ (b)-(e), 7.9 (c) (1949) ; Comment, 62 YALE L.J. 912, 917 (1953). Rules adopted in the Conferences are codified in the Federal Register, and copies are sent to each member of the industry. Id. at 921-43. The individual member may then sign and return the rules if he wishes to abide by them. Ibid. Signing is not compulsory, but failure to sign will not relieve a businessman from his duty to obey "Group I" Rules, which are restatements of the law adapted to the particular industry. See Kittelle \& Mostow, supra note 41, at 428. "Group II" Rules merely suggest practices the FTC hopes to encourage. See Comment, 62 Yale L.J. 912, 925 (1953). Even if the businessman has signed the rules, he cannot be prosecuted for a violation of Group II Rules.

43. Address by Howrey, Trade Practice Rules and the Cosmetic Indistry, May 12, 1954, at 2. See also Kittelle \& Mostow, supra note 41, at 428; Comment, 62 Y ALE L.J. 912, 935 (1953). However, although the Rules are not given de jure recognition, they are often equivalent to the law in a given industry and are likely to be valid evidence of it in FTC proceedings. Ibid. It is also possible that litigants in private suits may be able to use non-compliance with Group I Rules as evidence of a substantive violation. See id. at $943-44$.

44. Kittelle \& Mostow, supra note 41, at 435; Comment, 62 YALE L.J. 912, 917, 943 (1953). 
out. ${ }^{45}$ Rules now exist for almost two hundred industries, but their antitrust provisions are generally platitudinous; they deal primarily with unfair advertising practices. ${ }^{46}$ In the hands of the "new" FTC, however, they may become an important means of preventing borderline antitrust violations. ${ }^{47}$

An Advisory Committee on Cost Justification has been appointed to study the difficulties of distributional cost accounting and, if possible, suggest "guiding yardsticks" for the Commission to follow. ${ }^{48}$ Proof that price differentials reflect only "due" allowance for differences in the cost of distribution is an absolute defense to charges of price discrimination. 49 The "old" Commission was criticized for rejecting cost justifications that seemed consistent with the highest standards of accuracy of which cost accountants were then capable. ${ }^{.00}$

45. One of the major purposes of the Rules is to "ferret out and pinpoint the wilful violator." Howrey, $A$ Report of Progress, supra note 10, at 7.

46. See 2 CCH Trade Reg. ReP. Iff 20018-20227 (1954).

Usually, the Rules were centered upon unfair advertising and the antitrust provisions were "boiler plate" platitudes echoing the words of the statutes. See Comment, 62 YarE L.J. $912,929,951$ n.237 (1953). J. M. Clark has stated that businessmen are unlikely to agree to anything more restrictive than "innocuous platitudes." Clark, The Lazv and Economics of Basing Points: Appraisal and Proposals, 39 Ar. Econ. Rev. 430, 446 (1949). But sce the excellent and widely praised Rules governing the Cosmetics Industry, 16 FED. REG. 11993 (1951).

47. Optimistic predictions of success for the Practice Rules have not been fulfilled in the past. Cf. Atr'y GEN. Conrr. Rep. 370. And it is possible that businessmen simply will not adopt rules that significantly hamper some of their activities. See note 46 sufra. However, the atmosphere for successful adaptation is more promising under the "new" FTC because of its "pro-business" attitude and reputation. Cf. FTC ANN. REP. 52 (1954).

48. See Howrey, The Federal Trade Commission: A Revaluation of Its Responsibilities, 40 A.B.A.J. 113, 115-16 (1954); Howrey, $A$ Report of Progress, supra note 10, at 6 .

49. 49 Stat. 1526 (1936), 15 U.S.C. $\$ 13(a)$ (1952), amending $3 \$$ Stat. 730 (1914). The cost justification proviso was designed "to preserve for the consumer and the public the benefits of more efficient marketing methods, while at the same time protecting small buyers from 'unearned' discounts which were not related to savings in cost in serving the large buyer." Sylvania Electric Products, Inc., Docket No. 5728, 3 CCH TradE REg. REP. If 25197, at 35370 (FTC Oct. 27, 1954) (Howrey concurring).

"Distributional" costs are the costs a seller incurs in order to change the demand curve for his product. Chanderin, Theory of Monopolistic Competixion 117 (6th ed. 1948). They include the costs of advertising, promoting and maintaining a staff to sell the product. FTC Case Studies in Distribution Cost Accounting For Manufacturing \& Wholesaling, H.R. Doc. No. 287, 77th Cong., 1st Sess. 1 (1941) (hereinafter cited as FTC Case Studies). It is also possible, but far less common, to justify price differentials on the grounds of differences in the cost of production. See Comment, 49 Nw. U.L. REv. $237,238-39$ (1954). See note 208 infra.

50. Many critics have stated that the cost justification had become illusory. See, c.g., Atr'y Gen. ComMr. Rep. 171, 172; DirLAM \& KAHN, op. cit. supra note 3, at 123; Rowe, Price Discrimination, Competition, and Confusion: Another Look at Robinson-Patman, 60 YALE L.J. 929, 962-65 (1951). They point to the fact that in the period of almost twenty years since the Act was passed, only five cost justifications were successful in whole or in part, and that two of these occurred under the "new" Commission. See Comment, 49 Nw. U.L. REv. 237 n.2 (1954). Rowe, supra, at 964, went beyond the difficulty of proof 
For distributional cost accounting is in an incubational stage $:^{51}$ analyses are long and costly, ${ }^{52}$ and joint costs are not easily allocated. ${ }^{53}$ The accountant has not established uniform rules of procedure..$^{54}$

It may well be doubted that the "old" Commission was really too "tough" in its standards : $: 5$ Robinson-Patman places the burden of justification squarely upon the seller who discriminates in price. ${ }^{56}$ Until satisfactory standards can be reached, the FTC would not be justified in permitting estimates and averages to replace carefully documented and logically allocated cost studies.57 The "new" Commission will be more sympathetic to cost justifications, ${ }^{58}$ but

and argued that prices are related to demand, not to cost, and that the basic standard is in error. But see Chamberlin, op. cit. supra note 49, at 104.

51. See Atr'y Gen. Conm. Rep. 173; Comment, 49 Nw. U.L. Rev. 237, 239 (1954).

52. FTC Case Studics, op. cit. supra note 49, at 21-22. In some reported cases respondents who alleged that they had cost justifications chose to accept cease and desist orders rather than to undertake the costly analyses necessary to support their allegations. See Monolith Portland Cement Co., 47 F.T.C. 1292, 1298 (1951) ; Ideal Cement Co., 47 F.T.C. 1030,1036 (1951).

53. The main difficulty in distributional costing is that the costs are usually incurred "jointly," i.e., while serving many customers or while dealing with many commodities. It is necessary to analyze these composite costs, break them into their elements in terms of fiscal units, and then allocate to each customer the part of the costs attributable to his purchases. See FTC Case Studies, op. cit. stipra note 49, at 2.

54. See note 51 supra. The nature of the problem, see note 53 supra, indicates that it may be overly optimistic to expect universal rules to fit different situations: sellers' distributive arrangements are almost always sui generis. See FTC Case Studies, op. cit. supra note 49 , at 16 .

55. See Comment, 49 Nw. U.L. Rev. 237, 249 (1954).

InTERviews with Arthur E. Lundvall, Chief of the FTC Accounting Division, indicate that the "old" FTC's "toughness" was more apparent than real. In many instances valid cost justifications were established by informal conference and never reached litigation. Only dubious cases were litigated. Under these circumstances, a high mortality rate is not too surprising. For a businessman should not divide his costs unevenly among his customers unless he has good reason to do so.

56. 49 StaT. 1526 (1936), 15 U.S.C. \& 13(a) (1952), amending 38 STAT. 730 (1914). See FTC v. Morton Salt Co., 334 U.S. 37, $47-48$ (1948) ; Bruce's Juices, Inc. v. American Can Co., S7 F. Supp. 985, 989, 992 (S.D. Fla. 1949), aff'd, 187 F.2d 919 (5th Cir. 1951).

57. Cost differences cannot be established upon aggregates and averages: actual costs must be shown. See Bruce's Juices, Inc. v. American Can Co., supra note 56, 87 F. Supp. at 988; Russellville Canning Co. v. American Can Co., 87 F. Supp. 484, 494-95 (W.D. Ark. 1949). If joint costs are involved, their allocation must be based on a per-unit rather than per-customer system. Niehoff \& Co., Docket No. 5768, 3 CCH TRADE REg. REP. If 25467, at 35584 (FTC May 3, 1955); cf. FTC Case Studies, op. cit. supra note 49, at 2. And allocation must be based upon detailed analysis rather than lump-sum estimates. See Standard Oil Co., 41 F.T.C. 263 (1945), rev'd on other grounds, 340 U.S. 231 (1951); Standard Brands, Inc., 29 F.T.C. 121 (1949), aff'd, 189 F.2d 510 (2d Cir. 1951).

58. E.g., in Sylvania Electric Products, Inc., Docket No. 5728, $3 \mathrm{CCH}$ Trade REg. REP. If 25181 (FTC Oct. 1, 1954), the FTC permitted a cost justification that was based on a weighted-average rather than a per-unit basis. Sylvania sold a whole line of electronic tubes. It charged its retail dealers more per tube than it charged to Philco, which also bought tubes from it. The price differential varied from tube to tube.

Sylvania showed the actual costs of selling each tube in documented detail. In some 
it will still require documented analyses that make good accounting and antitrust sense. ${ }^{59}$ Therefore, if the Advisory Committee can arrive at workable standards it would be a major improvement in antitrust law : accountancy would follow the $\mathrm{FTC}^{60}$ and the businessman who wished to grant differentials based on cost savings would have a guide as to how much of a differential he might safely grant. It would be especially helpful if accounting standards could be written into each industry's Trade Practice Rules. ${ }^{61}$

Practice Rules and consensual arrangements can eliminate useless litigation and prevent borderline violations; they should be encouraged. ${ }^{62}$ But their use must be buttressed with investigative assurance that compliance habits actually mesh with compliance promises. The FTC is not sufficiently apprised of actual compliance with its orders and stipulations to make consensual arrangements truly effective. ${ }^{63}$ However, the Commission is determined to obtain stricter adherence to its orders than it has in the past, ${ }^{84}$ and it has made

instances differences in the cost of selling to Philco did not justify the differences in the price Philco got; in other instances, however, the differences were more than justified; and in the aggregate, there was substantial justification. The FTC permitted the justification in the aggregate because it found that the variations in the differentials among the types of tubes had no market significance. Demand for any given type of tube did not depend upon the tube's price; it depended on how fast the tube it was bought to replace wore out. This decision goes beyond the "old" Commission's costing policies. However, if it is limited to markets in which the cross-elasticity of demand is negative, it seems to be a reasonable extension. Of course, the costs themselves must be shown in detail; it is the justification that may be in the aggregate.

59. The Sylvania case, supra note 58, illustrates the accommodation of accounting theory to competitive realities. The accommodation must be made if the cost justification is to serve its purpose of rewarding efficiency but protecting equally efficient but smaller firms. See Atr'y Gen. CoMn. Rep. 173.

60. See Atr'y Gen. Consm. ReP. 173; FTC Case Studies, op. cit. supra note 49, at 12; cf. Comment, 49 Nw. U.L. Rev. 237, 251 (1954).

61. See FTC Case Studies, op. cit. supra note 49, at 12; Comment, 49 Nw. U.L. REv. 237, 250 (1954).

62. Sugar Institute, Inc. v. United States, 297 U.S. 553, 598 (1936) ; Eugene Dietzgen Co. v. FTC, 142 F.2d 321, 330 (7th Cir. 1944). The Atr'y GeN. Comm. Rep. concluded that more widespread use of consent orders should "improve vital consent processes," but it was wary of informal stipulations and Trade Practice Conferences. The Committee believed that enforcement difficulties made the use of the latter arrangements unsafe. See id. at $369-72$; cf. notes $63-65$ infra and accompanying text.

63. "With respect to most of its orders, the Commission does not now know with any degree of certainty whether or not the respondents have continued to be in substantial compliance." Address by Howrey, Compliance With Connission Orders, Sept. 21, 1953, at 2. There were 4,500 cease and desist orders outstanding when the "new" Commission took over. Ibid. There was no compliance information for $95 \%$ of the stipulations. Id. at 5. See also Atr'y Gen. Conrm. Rep. 373; H.R. Rep. No. 3236, 81st Cong., 2d Sess. 28 (1951).

64. INTERvrews with Commissioners and staff revealed that stricter enforcement of its orders is one of the keynotes of the "new" Commission. See also FTC ANr. REP. 40, 
substantial progress in reviewing and spot-checking compliance. ${ }^{65}$ When the FTC is in position to be sure that consensual orders are obeyed, their use should promote more efficient enforcement of the antitrust laws.

\section{Substantive Outlook of the "New" FTC}

The most significant change in antitrust policy introduced by the "new" Federal Trade Commission is its de-emphasis of per se presumptions of competitive injury in favor of "expert" market analysis. For example, practices proscribed by the Clayton Act are illegal only if their effect is or may be substantially to lessen competition. ${ }^{66}$ The "new" FTC has stated that it will examine relevant economic and marketing data in order to determine the probable effects of practices challenged under the Clayton Act; it will not

41 (1954) ; Kintner, supra note 4 , at 1150-51. Voluntary compliance will be stressed, but "all the compulsory procedures available to the Commission will be promptly applied and pressed" when there are indications that respondents are violating consensual orders or promises. Address by Howrey, Voluntary Compliance and Vigorous Enforcement, May 1954, at 2; see also Howrey, Compliance With Commission Orders, supra note 63, at 3. See note 65 infra.

The Commission has ample power to check on compliance with its orders. Rule of Practice 26 requires all respondents to file detailed, written reports of compliance within sixty days after an order is issued against them. 16 C.F.R. $\$ 2.26$ (1949). The Commission may also require from time to time, in its discretion, further written reports of compliance. $16 \mathrm{id}$. $\$ 2.26(\mathrm{~b})$. The Supreme Court upheld the exercise of the latter power even though it assumed the FTC was simply going on a "fishing expedition." United States v. Morton Salt Co., 338 U.S. 632, 641-43 (1950).

65. In 1954 the FTC undertook "a broadscale compliance program [including] ... a systematic and selective review of over 4,000 cease and desist orders, 8,000 stipulations and 2,000 trade practice rules." FTC Ann. Rep. 5 (1954) ; Howrey, A Report of Progress, supra note 10, at 6 . A special staff committee is studying past orders to see if they are still adequate under changed conditions; requesting special reports detailing compliance activities wherever information appears incomplete or outdated; and holding special conferences with respondents whenever compliance reports seem inadequate. The investigative staff is spot-checking compliance reports. See Howrey, Compliance With Commission Orders, supra note 63 , at 3-4.

INTERviEws with PGad B. Morehouse, who is directing this undertaking, indicate that by March of 1955 the FTC had checked through 1,200 of its outstanding orders. About 750 orders were approved, and supplemental reports were requested in about 450 instances. Twenty-eight field investigations were commenced to check reports against actualities. And 22 civil penalty suits for non-compliance are either pending or in the drafting stage. See also Howrey, Statement Before the Antitrust Subcommittee of the House Committee on the Judiciary 3-4 (1955) (mimeograph). The number of penalty suits being prepared exceeds the total number brought from 1947 to 1953 . Id. at 4.

66. See notes $88(\$ 3), 146$ (\$ 7), and 201 (Robinson-Patman Act) infra and accompanying text.

67. See, e.g., Maico Co., Docket No. 5822, 3 CCH Trade Reg. Rep. 111577 (FTC Dec. 7, 1953) ; Insto-Gas Corp., Docket No. 5851, 3 id. đ 25188 (FTC Oct. 6, 1954); Pillsbury Mills, Inc., Docket No. 6000, 3 id. If 11582 (FTC Dec. 28, 1953) ; General Foods Corp., Docket No. 5675, 3 id. II 25069 (FTC Apr. 27, 1954). Greater stress upon market analysis is the most important single change inaugurated by the Republican FTC. The 
rely on per se presumptions of competitive injury. ${ }^{68}$ It will consider both structural and behavioral analyses of the markets involved ${ }^{60}$ in order to determine whether the effect of the practices is or may be to lessen the "workability" of the competition in those markets. ${ }^{70}$ The most important indicia of "workable" or "effective" competition are: 1) ease of entry into the market for newcomers; 2) consumer and business alternatives, and competitive freedom to choose between them; 3) price competition and price flexibility; and 4) the opportunities for growth and survival open to competitors. ${ }^{71}$

Commission is using economic data at several levels: 1 ) in deciding whether to issue a complaint, both to evaluate the economic impact of the alleged violation and to judge the probable effectiveness of a cease and desist order; 2 ) in investigating the market practices involved; and 3) in developing an economic as well as a legal "theory of the case" for litigation. See Address by Howrey, Rczaluation of Commission's Responsibilitics, June 18,1953 , at 4 .

68. A "per se" rule is one whereby evidence of a few selective facts conclusively settles a different, ultimate issue of fact and/or law. Thus, proof of an agreement to fix prices is, per se, conclusive of an illegal restraint of trade under the Sherman Act; evidence that fixing the price was "good" or aided competition is irrelevant. See, e.g., United States v. Socony Vacuum Oil Co., 310 U.S. 150 (1940) ; United States v. Trenton Potteries Co., 273 U.S. 392 (1927).

Chairman Howrey has stated that "the expertise which the Commission is supposed to exercise plows barren ground if it is bound by absolute or per se rules; that it cannot acquire a special knowledge of competitive conditions and effects unless it examines all relevant economic factors. . . Howrey, Revaluation of Commission's Responsibilitics, supra note 67, at 2; Address by Howrey, Economic Evidence in Antitrust Cases, June 14,1954 , at 3.

69. Experts differ on the relative importance of structural and behavioral data in judging the workability of competition. Many stress market performance, i.e., the output, price flexibility and price sensitivity of an industry. See Mason, The Current Status of the Monopoly Problem in the United States, 62 Harv. L. REv. 1265 (1949) ; Oppenheim, Federal Antitnust Legislation: Guideposts to a Revised National Antitrust Policy, $50 \mathrm{MrcE}$. L. REv. 1139 (1952). Others give approximately equal weight to structure and perforinance. See Adams, The "Rule of Reason": Workable Competition or Workable Monopoly? 63 Y ALE L.J. 348, 366 (1954) ; Stocking, The Rule of Reason, Workable Competition and Monopoly, 64 YALE L.J. 1107 (1955); of. Rostow \& Sachs, Entry Into the Oil Refining Business: Vertical Integration Re-examined, 61 YALE L.J. 856 (1952). Still others believe that both are unreliable guides and propose instead the proscription of certain types of unfair conduct. See DrRLAM \& KAHN, op. cit. supra note 3, at 28-43; Kahn, Stantdards For Antitrist Policy, 67 Harv. L. Rev. 28, 29 (1953). The "new" FTC apparently will take both structure and performance into account. See Howrey, Revaluation, supra note 67 , at 2 ; cf. note 164 infra.

70. See FTC ANn. REp. 62 (1954). The atomistic, parimutuel competition of classical and neo-classical economics exists in very few markets. See note 269 infra. Therefore many economists and lawyers have insisted that antitrust policy should be re-oriented to the market realities of "workable" or "unworkable" competition, rather than a chimerical ideal of perfect competition. But it is not so clear just what the economists" concept of workable competition is, or how it fits into antitrust policy. See notes 125-30 infra.

71. Most economists and lawyers agree in general that these are the key signs to workable competition. Almost all lay the heaviest stress upon freedom of entry. See, c.g., AtT'y Gen. Comm. Rep. 325-30; Edwards, Maintaining Contpetition: Reguisites of a Governmental Policy 186 (1949). The main bars to free entry are 1) the economies 
The Commission's insistence upon market analysis will not preclude the use of presumptions of competitive injury. However, the presumptions will have to be based upon market evidence and market analysis. ${ }^{72}$ Furthermore, the presumptions will be rebuttable: respondents will be permitted to offer further evidence to show that, in the particular market situation, the inferences which would normally be drawn are not valid. ${ }^{73}$ Thus the questions for decision become how much and what sorts of market evidence are necessary in order to establish or rebut a prima facie case of competitive injury. No glib answer to these questions is possible; the answer will vary with the factual characteristics of the markets and firms involved. ${ }^{74}$ The "new" FTC will proceed on a case-by-case basis, and will not decide "how much" evidence is necessary until the parties, markets and types of practices involved have been delineated. ${ }^{75}$

The "new" FTC's insistence upon case-by-case market analysis is beyond reproach. The antitrust laws deal with market problems; they must be construed in terms of market standards and market analysis. ${ }^{76}$ The FTC should

of scale; 2) the existence of superior, efficient firms; 3) indispensable resources; 4) exclusive franchises and 5) high capital requirements. StIGLER, THE THEoRx OF PRTCE 222-28 (rev. ed. 1952). The FTC will stress ease of entry. Howrey, Economic Evidence in Antitrust Cases, supra note 68, at 6. But see the Spark Plug cases, Docket Nos. 3977, 5620, 5624, $3 \mathrm{CCH}$ Trade Reg. Rep. If 11467 (FTC July 10, 1953) (finding no likelihood of competitive injury even though discriminatory prices made entry functionally impossible).

72. See notes 67-70 supra. See also Howrey, The Robinson-Patman Act and a Prima Facic Case, 37 Geo. L.J. 541, 544-45 (1949).

73. The Commission will allow rebutting evidence because it feels that, as an "expert" agency, it can and must do so-even if the courts do not. "We believe that the structure of the Federal Trade Commission was specifically designed to make decisions involving this type of complex economic problem. To refuse to exercise our talents as an administrative tribunal in these cases because the courts feel 'ill suited' to weigh all of the relevant factors, would deprive the country of the very services which we were created to furnish." Maico Co., Docket No. 5822, 3 CCH Trade Reg. Rep. If 11577 (FTC Dec. 7, 1953) ; see also Insto-Gas Corp., Docket No. 5851, 3 id. II 25188 (FTC Oct. 6, 1954) ; Pillsbury Mills, Inc., Docket No. 6000, 3 id. If 11582 (FTC Dec. 28, 1953).

74. See Pillsbury Mills, Inc., supra note 73; Address by Howrey, The Federal Trade Commission and the Administrative Process, Jan. 28, 1954, at 7. The Commission will refrain from basing its decisions on "quantitative" standards. See cases cited note 73 supra. Thus quantitative comparisons would have utility, if at all, only when based upon analogy or upon prior decisions in the same industry. The semantic standard will remain the same-a reasonable probability of substantial injury to competition. But what is "reasonable," "probable" or "substantial" will vary with the circumstances. See General Foods Co., Docket No. 5675, 3 CCH TRAde Reg. Rer. If 25069 (FTC April 13, 1954).

75. See Pillsbury Mills, Inc., Docket No. 6000, 3 CCH Trade Reg. Rep. \ 11582 (FTC Dec. 28, 1953).

76. "For the distinction between competition and monopoly turns on power in a relevant market." ATr'Y Gen. Comr. Rep. 44. See also id. at 48; Lockhart \& Sacks, The Relerance of Economic Factors in Determining Whether Exchusive Arrangements Violate Section 3 of the Clayton Act, 65 HARv. L. Rev. 913, 933-41 (1952). The "market" is the "area of effective competition." It must be described both geographically and in terms of "yatterns of trade which are followed in practice. ..." Standard Oil Co. v. United 
not recognize a prima facie case of illegality until its counsel have described the parties, practices and markets involved in terms of market operation. The markets should be delineated in terms of their competitive significance to the various parties. ${ }^{77}$ The parties should be delineated in terms of their comparative market power and comparative market shares rather than in dollar and volume terms alone. ${ }^{78}$

However, the FTC should find a prima facie case of competitive injury once there is enough evidence to make it reasonable to presume in a particular case that the kind of behavior described, in the kind of market defined, by the kind of businessman involved, will normally tend to injure competition. ${ }^{70}$ Normal market consequences should be presumed once the parties, markets and practices have been sufficiently defined to indicate what would normally follow. ${ }^{79}$ Evidence of all possibly relevant economic factors should not be required in order to establish a prima facie case. ${ }^{80}$ If there are special circumstances in

States, 337 U.S. 293, 299 n.5 (1949) (popularly referred to as the "Standard Stations" case). See United States v. Columbia Steel Co., 334 U.S. 495, 508-18 (1948) ; Indiana Farmers' Guide Publishing Co. v. Prairie Farmer Publishing Co., 293 U.S. 268, 279 (1934).

77. Thus, in United States v. Columbia Steel Co., 334 U.S. 495 (1948), the Supreme Court examined the market, isolated the factors governing entry into the market, and then looked to see whether defendant controlled those factors. Id. at 50S-18. See Rostow, Monopoly Under the Sherman Act: Power or Purpose?, 43 ILL. L. Rev. 745, 779 (1949). Cf. note 102 infra. Thus, in effect, the "market" was defined in terms of ability to foreclose entry. Furthermore, the strategic importance of a market in reaching the consumer may often be important in deciding its significance as the "relevant" market. See Kevlon Products Corp., Docket No. 5865, 3 CCH Trade REg. Rep. I 25184 (FTC Oct. 1954); Harley Davidson Motor Co., Docket No. 5768, 3 id. If 25108 (FTC June 1954).

78. See Barnes, Economic Issues in the Regulation of Acquisitions and Mcrgers, 14 Oнто ST. L.J. 279, 298-99 (1953) ; cf. Lockhart \& Sacks, supra note 76, at 941; Schwartz, Potential Impairment of Competition-The Impact of Standard Oil of California v. United States on the Standard of Legality under the Clayton Act, 98 U. PA. L. KEv. 10, 19 (1949). This is the position adopted by the "new" FTC. See cases cited note 67 supra.

79. Evidence delineating parties, practices and markets should be taken as circumstantial evidence of the effects that would normally follow. One of the purposes of cultivating an agency with empirical "expertise" is to prepare it to determine what will normally follow from such a market picture. But it should not be necessary to draw the market picture in minute detail. For the competitive impact clauses of the Clayton Act were intended to strike down potentially restrictive practices before they could restrain trade. See S. REP. No. 1775, 81st Cong., 2d Sess. 4-5 (1950) ; H.R. REP. No. 1191, \$1st Cong., 1st Sess. (1950) ; AtT'y Gen. Comar. Rep. 117; cf. Lockhart \& Sacks, supra note 76 , at 938 . So long as the prohibited effects may reasonably be presumed from the competitive picture drawn in each case, no more should be required for a prima facie case of illegality. Cf. Otis Co. v. SEC, 176 F.2d 34, 43 (D.C. Cir. 1949).

80. There are innumerable factors that may be considered in determining probable effects. Not all of these factors need be presented to establish a prima facie case of probable harm. See ATr'y Gen. Comm. ReP. 123-26; Oppenheim, supra note 69, at 1158 . Probably as many of them as possible should be considered before deciding which cases to investigate or prosecute. See Barnes, supra note 78 , at 290 . But if counsel supporting the complaint has brought forward valid evidence indicating a likelihood of harm, respondent should bear the burden of coming forward with other factors tending to contradict counsel's case. See note 82 infra. 
the relevant market, respondent should be allowed to prove their existence and effects. ${ }^{81}$ But the burden of alleging and proving special circumstances must fall on the respondent. ${ }^{82}$ He should be familiar with the marketing peculiarities of his industry. ${ }^{33}$ Once relevant rebutting evidence has been introduced, however, the scope of the inquiry should be as wide as the relevance of the evidence. ${ }^{8 *}$

Wider economic inquiry, keyed to a flexible use of the rebuttable presumption, will bring the "new" FTC closer to the legislative purpose of Congress in creating a specialized, expert Commission. ${ }^{85}$ So long as the economic evidence it considers is relevant, and the amount it requires to establish or rebut a prima facie case of illegality does not alter the substantive requirements of the antitrust law, the Commission should be permitted to determine the limits of its capacity for expert analysis. ${ }^{80}$

However, some of its decisions indicate that the "new" FTC is altering substantive standards which the Supreme Court has established. Developments in three areas warrant extended comment: 1) exclusive dealing and tying arrangements, under section 3 of the Clayton Act; 2) mergers, under section 7 of the Clayton Act; and 3) territorial price discriminations, under the Robinson-Patman amendment to the Clayton Act. ${ }^{87}$ Analysis of recent cases

S1. See note 73 supra.

S2. "[T] he proponent of any factual proposition shall be required to sustain the burden of proof with reference thereto." FTC Rule of Practice 18, 16 C.F.R. \$ 2.18(a) (1949); see Administrative Pracedure Act, 60 StAT. 241 (1946), 5 U.S.C. $\$ 1006(c)$ (1952). Cf. Oppenheim, supra note 69, at 1159-60; Adams, supra note 69, at 354-55.

83. The jurisdiction of the FTC is enormous and the amount of funds with which it works is limited. See FTC Report on Corporate Mergers and AcQuisitions 175-80 (hereinafter cited as MERGER REPORT); cf. Dession, The Trial of Economic and Technological Issues of Fact, 5S YALE L.J. 1019, 1242 (1949). The respondent is in a superior position to know about special circumstances and market peculiarities existing in his line of trade. The balance of convenience indicates that the burden of introducing detailed evidence of structural idiosyncracies should therefore lie with respondent. See Automatic Canteen Co. v. FTC, 346 U.S. 61, 7S (1953).

84. FTC counsel should be free to expand the scope of the inquiry, if necessary, to surrebut respondent's evidence. Thus, more elements would be considered in determining what is "reasonably probable." See Lockhart \& Sacks, supra note 76, at 929, 938; Oppenheim, supra note 69 , at $1158-60$.

85. See notes 10,76 supra. "The courts consistently have recognized that the Commission was created for the purpose of appraising economic data and market facts, and they have repeatedly declared that the courts are ill-suited to perform such functions." Howrey, FTC and The Administrative Process, supra note 74, at 8. See FTC v. Motion Picture Advertising Serv. Co., 344 U.S. 392, 394 (1953) ; Standard Oil Co. v. United States, 337 U.S. 293, 310 n.13, 322 (1949) ; DIRLAM \& KAHN, op. cit. supra note 3, at 103. But sec Note, 55 Colum. L. Rev. 561, 564 (1955), which states that the FTC was created to reach violations that the courts could not or would not reach, and that "it is at least anomalous that the Commission will sanction activity which the courts find illegal."

S6. See notes $290-91$ infra and accompanying text.

87. For discussions considering other recent FTC decisions, see Kintner, stupra note 4; Loescher, Incrt Antitrust Administration-Formilla Pricing and The Cement Industry, 65 Y YLF. L.J. 1 (1955) (basing point cases); Sunderland, supra note 7. 
in these areas will indicate the extent and nature of the FTC's departures from established standards of antitrust law and policy. It will also prepare the way for a fuller discussion of whether the FTC is free to depart from these standards; and, if it is not, how to reconcile disparities without unduly limiting the Commission's freedom to apply its "expertise" to the market problems of particular cases.

\section{Enforcement of section 3 of the Clayton Act by the "New" FTC}

Section 3 of the Clayton Act proscribes exclusive dealing and tying arrangements the effect of which is or may be "to substantially lessen competition or tend to create a monopoly in any line of commerce." 88 By an exclusive dealing arrangement, the seller predicates the sale of a desirable product upon the "condition, agreement or understanding" that the buyer will take all he needs of that product exclusively from the seller. ${ }^{89}$ By a tying arrangement, the seller predicates the sale of a desirable product (the "tying" product) upon the "condition, agreement or understanding" that the buyer will also buy another, different product (the "tied" product) from the seller. ${ }^{90}$

The Clayton Act does not differentiate between exclusive dealing and tying arrangements, but the courts have established different standards for the legality of each. ${ }^{91}$ Both types of arrangements, by their nature, foreclose the seller's competitors from access to segments of the market, ${ }^{92}$ and the Supreme

88. 38 STAT. 731 (1914), 15 U.S.C. $\$ 14$ (1952). The more important legislative history of the Clayton Act is cited in Schwartz, Potential Impairment of CompetitionThe Impact of Standard Oil of California v. United States on the Standard of Legality Under the Clayton Act, 98 U. PA. L. REv. 10, 21 n.40 (1949). See also Lockhart \& Sacks, The Relevance of Economic Factors in Determining Whether Exclusive Arrangements Violate Section 3 of the Clayton Act, 65 HARv. L. Rev. 913, 933-36 (1952).

89. See Note, 49 Colum. L. Rev. 241,242 (1949).

An exclusive dealing arrangement may come within the statute even though there is not a contract, so long as a condition or understanding is shown. United States v. Richfield Oil Co., 99 F. Supp. 280, 294-96 (S.D. Cal. 1951), aff'd per curian, 343 U.S. 922 (1952) ; Carter Corp. v. FTC, 112 F.2d 722, 732 (8th Cir. 1940); Lockhart \& Sacks, supra note 88, at 920 ; cf. Note, An Interstate Circuit Approach to the Refusal to Deal Dilemma Under Section 3 of the Clayton Act, 64 YALE L.J. 581 (1955).

90. See J. L. Thompson Mfg. Co. v. FTC, 150 F.2d 952, 955 (1st Cir.), cert. denied, 326 U.S. 776 (1945); Note, 49 ColuM. L. REv. 241, 242 (1949). Tying arrangements are generally a form of full-line forcing, the tying product being closely related to the use of the tied. Lockhart \& Sacks, supra note 88, at 943; Note, 63 YALE L.J. 389 (1954). Here too, the agreement need not be overt if there is an understanding. See United States v. Griffith, 334 U.S. 100, 108 (1948) ; Note, 63 YALE L.J. 389 n.1 (1954).

91. Compare Standard Oil Co. v. United States, 337 U.S. 293 (1949) (exclusive arrangements), with Times-Picayune Publishing Co. v. United States, 345 U.S. 594 (1953) (tying arrangements). See text accompanying notes 96,99 infra.

92. Standard Oil Co. v. United States, supra note 91, at 314; Times-Picayune Publishing Co. v. United States, supra note 91, at 604-05; International Salt Co. v. United States, 332 U.S. 392, 396 (1.947). "Foreclosure" is, in this sense, a term of art meaning that one businessman's conduct has insulated him, pro tanto, from the necessity of competing with other (existing or potential) businessmen; it does not necessarily mean that 
Court has stated that "it is unreasonable, per se, to foreclose competitors from any substantial market."93 But tying arrangements are usually forced upon a buyer by a more dominant seller, ${ }^{94}$ and they serve hardly any economic purpose besides foreclosing markets. ${ }^{95}$ Therefore, in the Times-Picayune case, the Supreme Court stated that these arrangements are illegal per se if the seller is "dominant" in the market for the tying product, or if a substantial amount of commerce is restrained in the market for the product tied. ${ }^{96} \mathrm{Ex}$ clusive arrangements, in contrast, may be "responsive to genuine market demands," and may aid competition rather than reduce it. ${ }^{97}$ But the Supreme Court has declined to go into the market problems involved in weighing their actual, short-term effects upon competition, ${ }^{98}$ and in Standard Stations it held that it was illegal per se for a major seller to use exclusive contracts which foreclosed competitors from access to a substantial share of the market and from a substantial volume of business. ${ }^{99}$

competing businessmen cannot sell their goods. See symposium statements of Judge Stanley N. Barnes, Assistant Attorney General, and Professor Louis B. Schwartz. Hearings Before the Select Committee on Small Business to Consider the Atty Gen. Comm. Rep., S4th Cong., 1st Sess. 63 (1955) ; Revlon Products Corp., Docket No. 5685, 3 CCH TRADE REG. REP. ๆ 25184 (FTC Oct. 1954).

93. International Salt Co. v. United States, supra note 92, at 396. See also United States v. Griffith, 334 U.S. 100, 107 (1948).

94. See Mreler, Unfair Competition 199 (1941); Norwood, Trade Practices \& Price LAw c. 14 (1938); Note, 49 Colum. L. Rev. 241, 246 (1949); cf. Times-Picayune Publishing Co. v. United States, 345 U.S. 594, 605 (1.953) ; Lockhart \& Sacks, supra note 88, at 942; Note, 63 Y ALE L.J. 389 (1954). The amount of coercion the seller can bring to bear will, of course, vary inversely with the substitutes for the tying product that are commercially available to the buyer.

95. Times-Picayune Publishing Co. v. United States, supra note 94, at 604; Standard Oil Co. v. United States, 337 U.S. 293, 305 (1949); International Salt Co. v. United States, 332 U.S. 392, 396 (1947).

96. Times-Picayune Publishing Co. v. United States, 345 U.S. 596, 606-09 (1953) (dictum), and cases there cited. Times-Picayune was tried under the Sherman Act standard, which was held to require a showing of both factors. Ibid. A patent on the tying product is at least prima facie evidence of dominance. Id. at 608; International Salt Co. v. United States, supra note 95, at 395-96; NoRwoon, op. cit. supra note 94, at c. 15.

97. Stockhausen, The Commercial and Antitrust Aspects of Term Requirements Contratts, 23 N.Y.U.L.Q. Rev. 412, 414, 428 (1948). See also ATT'y GEN. CoMm. Rep. 138; DIRLAMI \& KAHN, op. cit. supra note 3, at 185, 189; EDwards, op. cit. supra note 71, at 176: Lockhart \& Sacks, supra note SS, at 919-20. They may not only be non-coercive, and mutually beneficial to both parties, but above all they may "fortify the market position of weaker competitors ... and enable new entrants to gain a foothold by assuring a set volume of business for a critical starting period." ATT'Y GEN. CoMm. Rep. 145. See notes 115-17 infra and accompanying text.

98. Standard Oil Co. v. United States, 337 U.S. 293, 309-10 (1949). See also United States v. Richfield Oil Corp., 99 F. Supp. 280 (S.D. Cal. 1951), aff'd per curiam, 343 U.S. 922 (1952); Anchor Serum Co. v. FTC, 217 F.2d 867, 871 (7th Cir. 1954) ; Dictograph Products, Inc. v. FTC, 217 F.2d 821, \$27-28 (2d Cir. 1954).

99. Standard Oil Co. v. United States, 337 U.S. 293 (1949).

There is a wide difference of opinion as to just what Standard Stations held. The current view seems to be that the substantial share of stations which Standard tied up with 
The "new" FTC appears to have accepted the standards of TimesPicaynne, ${ }^{100}$ but it has stated that it will not follow Standard Stations. ${ }^{101}$ It will presume the likelihood of competitive injury from proof that exclusive contracts foreclosed a leading seller's competitors from access to a substantial share of the market. ${ }^{102}$ But that presumption is not conclusive; it may be

exclusive contracts created the inference of foreclosure of market outlets that, in turn, created the inference of probable injury. See ATr'y GEN. CoMrr. REP. 141-42; Lockhart \& Sacks, supra note 88, at 916, 931. But others have taken the case to mean that the contracts were illegal because the quantitative volume of sales affected was substantial. See Transamerica Corp. v. Board of Governors, 206 F.2d 163, 170 (3d Cir.) (dictum), cert. denied, 346 U.S. 901 (1953) ; Oppenheim, Federal Antitrust Legislation: Guidcposts to a Revised National Antitrust Policy, 50 Micr. L. Rev. 1139, 1180 (1952). Schwartz, supra note 88 , at 14 , thought the case turned on substantial volume, but only when the contracts were used by a market leader. This interpretation also seems quite tenable.

The difficulty arises because the Standard Stations case mentioned a number of factors bearing on competitive effect without ever specifying which, if any, was the significant one. It pointed out that Standard was not "dominant," Standard Oil Co. v. United States, supra at 302 , but it was the leading seller in a saturated market area, selling $23 \%$ of the gallonage in the market. Id. at 293-95. And although it stated that the percentage of market shares involved (16\% of the independent gas stations) was the most important factor, $i d$. at 295,308 , it also seemed to peg the potentiality of harm directly on the substantial number of stations affected. Id. at 311 .

However, one thing is clear. Whatever the factors upon which the case turned, the Court was convinced that when those factors were present that was the end of the case. Id . at 309,310 . The Court recognized that evidence of lowered costs, reasonable length, etc., might be pertinent to the contracts' short-run effect, $i d$. at 306,308 , but it thought that their probable long-run effect of barring entry and diminishing competition outweighed short-run economic justification. Id. at 308, 309. And it thought evidence of flourishing competition was inconclusive and immaterial. Id. at 310-14. It is possible to argue that this exclusion was based upon statutory construction, id. at 308-09, or upon the Court's inability and unwillingness to become embroiled in complex economic problems, id. at $310 \mathrm{n} .13$. But whatever its rationale, the Court did hold that the presence of the critical factors created a conclusive presumption of injury.

100. Insto-Gas Corp., Docket No. 5851, 3 CCH TrADE Reg. Rep. đI 25188 (FTC Oct. 6, 1954). See notes 131-45 infra and accompanying text.

101. "From our reading of the statute, we cannot conclude that evidence of the effect ... is immaterial. . . . The Supreme Court did not require evidence of competitive effect under the circumstances of the Standard Stations case, ruling that it was sufficient to show that competition had been foreclosed in a substantial share of the line of commerce affected. In its decision, it stated that courts were most ill-suited to make an appraisal of economic data to determine the actual effect....

"It is significant that at the same time the Court pointed out the Federal Trade Commission was adequately equipped to weigh all relevant economic factors." Maico Co., Docket No. 5822, 3 CCH TRADE Reg. Rep. đ 11577 (FTC Dec. 7, 1953).

102. See Anchor Serum Co., Docket No. 5822, 3 CCH Trade REg. Rep. $\{11634$ (FTC Feb. 1954); Harley Davidson Motor Co., Docket No. 5768, 3 id. đI 25108 (FTC June 1954); Revlon Products Corp., Docket No. 5685, 3 id. đI 25184 (FTC Oct. 1954). In Revlon, respondent had argued that its sales under exclusive contracts were not substantial in terms of the national market for cosmetics. The FTC held, however, that the purpose of considering the volume of sales was to determine whether their use was likely to lessen competition. And the Commission found a substantial likelihood of injury not 
rebutted by further proof that the foreclosures did not in fact, and do not tend, substantially to lessen competition. ${ }^{103}$

\section{Exclusive Dealing Contracts}

In the Maico case the "new" FTC held that, unlike the courts, it would consider rebutting market evidence offered by respondent to show the "actual effect" of exclusive dealing contracts. ${ }^{10 t}$ Maico, one of the nation's six largest hearing aid manufacturers, established 123 exclusive retail outlets between 1945 and 1950. ${ }^{105}$ The hearing examiner, relying on Standard Stations, held that Maico's size, its rapid growth, and the large number of dealerships it had established made its use of exclusive contracts illegal. ${ }^{100}$ Therefore he refused to permit Maico to introduce evidence that the number of dealers with whom it had exclusive contracts constituted only a small percentage of the hearing aid dealers in the nation, and that the number of its competitors and the volume of their business was increasing while its own market share was on the decline. ${ }^{107}$ On appeal the FTC apparently held that a prima facie case of illegality had been established, but it remanded the order to cease and desist because it thought the excluded evidence had a "very real bearing" on the

in the annount of sales but in the market importance of the share of dealers Revlon, a market leader, had under contract: 176 of 1,100 first-class beauty shop jobbers. Id. at p. 35331 .

103. See Maico Co., Docket No. 5822, 3 CCH Trade Reg. Rep. II 11577 (FTC Dec. 1953) ; Beltone Hearing Aid Co., Docket No. 5825, 3 id. II 11657 (FTC March 1954); Outboard Marine Co., Docket No. 58S2, 3 id. I 11657 (FTC March 1954); Howrey, $A$ Report of Progress, supra note 10, at 2; Note, 55 ColuM. L. REv. 561, 563 (1955). See also notes 104-09 infra and accompanying text.

104. Maico Co., supra note 103.

105. Ibid.

Actually, Maico had 123 franchised dealers and 58 sub-distributors, giving it 181 exclusive retail outlets. See Maico Co., Initial Decision, Docket No. 5822, at 3. There are only 1,000 "established, responsible" hearing aid dealers in the nation. See Dictograph Products, Inc., Docket No. 5655, 3 CCH Trade Reg. Rep. If 11526, at p. 12505 (FTC Sept. 1953), aff'd, 217 F.2d $S 21$ (2d Cir. 1954). In return for exclusive dealing, Maico gave its retailers exclusive territorial franchises. Maico Co., Initial Decision, at 3 . It enforced its exclusive contracts by cancelling some franchises when dealers refused to comply. See id. at 4-5; Commission Exhibits 20, 21, in the Maico Record.

Maico is either the fourth, fifth or sixth largest hearing aid manufacturer in the nation, although no evidence of market shares was introduced to establish its rank, which was based on the word of one of its executives. See Maico Co., Initial Decision, at 2; Respondent's Appellate Brief at 8 ; Record at 56 . Its sales, however, reached almost $\$ 2$ million annually from 1947-1949, triple the volume it sold in 1945 when it inaugurated the exclusive contracts. Maico Co., Docket No. 5822, 3 CCH Trade Reg. Rep. II 11577 (FTC Dec. 7, 1953).

106. See ibid; Initial Decision at 5 .

107. Ibid. Respondent's Appellate Brief had argued that:

1) Respondent had brought each of its dealers into the market, so that there could be no foreclosure. $I d$. at 9 .

2) The exclusive territorial contracts it gave its dealers precluded it from selling 
question of competitive injury. ${ }^{108}$ It stated that the conclusive presumption of Standard Stations was not intended to restrict the scope of inquiry permitted to an expert agency. 109

In most respects, the FTC's remand seems consistent with better antitrust policy. During their term, exclusive dealing contracts necessarily foreclose a seller's competitors from access to market outlets. ${ }^{110}$ If a seller enters into exclusive contracts with a substantial share of the buyers in the market, that will ordinarily tend substantially to lessen competition between him and his competitors. ${ }^{111}$ Thus, it should be illegal prima facie. ${ }^{112}$ It ordinarily puts the seller's competitors at a disadvantage pro tanto and precludes the buyer from exercising free market choice; it ordinarily impedes entry by new firms and clogs opportunities for small firms to expand. ${ }^{113}$ But it need not. ${ }^{114}$ Exclusive

to others in that market, so that it could not block entry or establish a monopoly. Id. at $28-30$.

3) The dealers constituted only a small percentage of all hearing aid dealers. Id. at 12 .

4) Its sales and market share had declined in the past three years. Id. at 7, 13.

See Maico Record, p. 202-06 (evidence proffered but not received); $i d$. at 150-51 (evidence stricken); $i d$. at 196-97 (proffered).

108. Maico Co., Docket No. 5822, 3 CCH Trade Reg. Rep. II 11577 (FTC Dec. 7, 1953). The FTC was not explicit on the establishment of a prima facie case, but the remanding order accompanying the decision denied respondent's request that the proceedings be dismissed. And Maico's subsequent consent to a cease and desist order when it was unable to produce sufficient evidence for rebuttal purposes further indicates the text's proposition. See Consent Order, Docket No. 5822, 3 CCH Trade Reg. Rep. $\llbracket 25475$ (FTC June 3, 1955).

109. See note 101 supra.

110. See Standard Oil Co. v. United States, 337 U.S. 293, 314 (1949); ATr'y Gen. CoMrar. Rep. 138; Lockhart \& Sacks, supra note 88, at 922.

111. See Standard Oil Co. v. United States, 337 U.S. 293, 309, 314 (1949) ; United States v. Richfield Oil Corp., 99 F. Supp. 280, 284-86 (S.D. Cal. 1951), aff'd per curiam, 343 U.S. 922 (1952) ; Dictograph Products, Inc. v. FTC, 217 F.2d 821, 828 (2d Cir. 1954); AtT'y Gen. Cosrar. Rep. 41-42. If the seller is the leader in the relevant line of commerce, that would probably be sufficient in itself. See Standard Fashion Co. v. Magrane-Houston Co., 258 U.S. 346 (1922); Kahn, A Legal and Economic Appraisal of the "Neze" Sherman and Clayton Acts, 63 Y ALE L.J. 293, 317 (1954); Schwartz, supra note 88, at 28.

112. See notes 76-80 supra and accompanying text.

113. If a substantial share of the buyers in the market are bound by contract not to purchase from competing sellers, the seller is immunized from competition pro tanto, and the buyers are not free to change to superior or less expensive products. This would tend to create an undesirable price rigidity, varying directly with the length of the contract and the ability of the seller to enforce it. And as the share of buyers increases, whether under contract to one seller or to a group of leading sellers, it becomes more and more difficult for smaller competitors, who are unable to finance their own outlets, to reach the buying public. See Standard Oil Co. v. United States, 337 U.S. 293, 309 (1949) ; Enwarps, op. cit. supra note 71, at 175 et seq.; Revlon Products Corp., Docket No. 5685, $3 \mathrm{CCH}$ Trade Reg. Rep If 25184 (FTC Oct. 5, 1954).

114. "[T]he desirability of any exclusive dealing or use arrangement in the light of the national policy to preserve competition cannot be decided merely by reference to the quantity or share of commerce affected." Lockhart \& Sacks, supra note 8S, at 919. See id. at $923-28$ for a listing of other considerations the authors deem relevant to the ques- 
contracts may reflect market savings to buyers as well as sellers; they do not necessarily indicate use of monopolistic leverage by the seller. ${ }^{115}$ If they are responsive to the technological needs of an industry, and are entered into for only a limited period, they may not tend seriously to lessen competition in that industry. ${ }^{116}$ Moreover, when used by a small firm attempting to break into, or expand its position within, a relatively non-competitive industry, these contracts may even tend to increase competition. ${ }^{117}$ Therefore, rebutting evidence that particular contracts were not forced upon unwilling buyers and are not likely to lessen competition should not be excluded.118 The types of evidence admitted should be limited; the risk of non-persuasion should lie with the seller; but the opportunity for rebuttal should not be foreclosed. ${ }^{119}$

The evidence Maico sought to introduce to show that its dealers constituted only a small percentage of the dealers in the nation certainly should not have been excluded. The inference of a "substantial" lessening of competition is drawn from a showing that access to a "substantial" share of the dealers in the market was foreclosed. ${ }^{120}$ In this context "substantial" is not necessarily synonymous with "sizable"; it means "substantial enough" to permit certain

tion of injury. See also ATt'y GeN. CoMir. REP. 138, 144; DiRLAM \& KAHN, op. cit. supra note 3, at 185, 189; EDWARDs, op. cit. supra note 71, at 176; Stockhausen, supra note 97, at $414,424,428$. See note 97 supra.

115. See authorities cited notes 97,114 supra. The fact that the buyer sought the exclusive contract, and was not a victim of coercion, is irrelevant if there is a likelihood of competitive injury. Anchor Serum Co., Docket No. 5965, 3 CCH TRAdE REg. REP. If 11634 (FTC Feb. 1954), aff'd, 217 F.2d 867, 870 (7th Cir. 1954). However, coercion by a leading seller is one of the "badges" of probable injury to competition. See FTC v. Motion Picture Advertising Serv. Co., 344 U.S. 392, 396 n.3 (1953) ; United States v. Standard Oil Co., 78 F. Supp. 850, 857, 859, 886 (S.D. Cal. 1948), aff'd, 337 U.S. 293, 309 (1949); Kahn, sutpra note 111, at 317-18.

116. See FTC v. Motion Picture Advertising Serv. Co., 344 U.S. 392 (1953) ; United States v. American Can Co., 87 F. Supp. 18 (N.D. Cal. 1949) ; cf. Standard Oil Co. v. United States, 337 U.S. 293, 307 (1949). Although there is bound to be some potential lessening of competition, the practicalities of business intercourse should be given weight so long as there is no substantial impediment barring new firms from coming in and stirring up new methods of business. See Atr'y Gen. CoMm. REP. 144, 146; DiRlam \& $\mathrm{KAHN}$, op. cit. supra note 3, at 113, 119; Kahn, supre note 111, at 316-17; Lockhart \& Sacks, supra notaes, at 921; Stockhausen, supra note 97, at 421.

117. AtT'y Gen. ComMr. Rep. 145; DirlaMr \& KAHN, op. cit. supra note 3, at 117-19. Congress did not intend to proscribe the use of exclusive contracts by new or small firms. See Lockhart \& Sacks, supra note 88, at 931-36.

118. Atr'Y Gen. Comm. Rep. 138-44; Lockhart \& Sacks, supra note 88, at 919.

119. See notes 73, 81-84 supra and accompanying text.

120. See Standard Oil Co. v. United States, 337 U.S. 293, 308 (1949) ; ATr'y GEN. CoMM. ReP. 141-42; DrRLAM \& KaHN, op. cit. supra note 3, at 117. See notes 92, 110-13 supra and accompanying text.

The foreclosure need not be complete so long as a large share of the better outlets are closed. See Revlon Products Corp., Docket No. 5685, 3 CCH Trade Reg. Rep. I 25184 (FTC Oct. 7, 1954). Moreover, if exclusive contracts are used by a seller's competitors also, it may be sufficient that a substantial share of the market's outlets are foreclosed in the aggregate. See $i d$. at p. 35332; cf. Standard Oil Co. v. United States, supra at 295, 309; FTC v. Motion Picture Advertising Serv. Co., 344 U.S. 392, 393 (1953). 
inferences to be drawn. ${ }^{121}$ A given percentage may be "substantial" in one market and "insubstantial" in another because of the size of the industry, the size and standing of the firms within it, and the costs and incentives of entry. ${ }^{122}$ And if counsel has restricted the definition of the market to a limited line of commerce or a limited geographical region, respondent might show that the limitations were not competitively realistic. ${ }^{123}$ In a re-defined market the same absolute number would constitute a different percentage, which might or might not be "substantial." Respondents should be held to a strict burden of proof, but they should always be permitted to show that the number of outlets foreclosed was not "substantial" in terms of numbers, percentages, markets or market significance-in terms of reasonable probabilities of lessening competition. . $^{124}$

However, proof of "workable" competition should not constitute a valid rebuttal to a prima facie case. ${ }^{125}$ The evidence Maico offered in order to prove that its competitors were gaining on it notwithstanding its use of exclusive

121. See Atr'y Gen. Comm. Rer. 123-26; Effective Competition, supra note 5, at 12; Barnes, Economic Issues in the Regulation of Acquisitions and Mergers, 14 Oн1о ST. L.J. 279,296 (1953). This may lead to a new Rule of Reason to be used in deciding whether Clayton Act offenses "may" lessen competition. See Kahn, supra note 111, at 313, 316-17. So long as the burden of persuasion and introduction is on respondent, and the rule is directed towards determining whether practices tend to lessen competition, rather than whether competition itself is desirable, such a rule would be proper. Cf. Stocking, The Rule of Reason, Workable Competition and Monopoly, 64 YALE L.J. 1107, 1159-60 (1955).

122. A percentage figure of, perhaps, $1 \%$, will always be de minimis; and one of $20 \%$ or more, probably, should always be substantial. See Statement of Professor Walter Adams, Hearings, supra note 92, at 55. However, these cases seldom arise. And in the gray area between, one must know the structure and practices of the industry before being able to determine when a percentage is significant. See Barnes, supra note 121, at 295-96; ATT'Y GEN. COMM. REP. 147; notes 120-22 supra and accompanying text. Thus, although the "progressiveness" of an industry seems entirely irrelevant to the inquiry, see notes 125-30 infra and accompanying text, evidence that entry is difficult at the dealer level would make a percentage figure more "substantial" than if entry were easy. For in the former instance foreclosure becomes even more significant: competitors are not only precluded from doing business with buyers currently under exclusive contracts, they are also dissuaded from establishing new outlets of their own. Thus they may be effectively foreclosed from the consumers' market also. See note 128 infra and accompanying text.

123. Respondent should be able to introduce evidence of "patterns of trade," including evidence of substitute products, which would call for a broader definition of the market. See Atr'y Gen. Comm. Rep. 46; Barnes, supra note 121, at 296; Stockhausen, supra note 97 , at 428. Of course, he would have to prove the substitute products were "actually competitive." ATT'y GEN. CoMM. REP. 46. The courts, adopting the economists' jargon, have required a showing of a high "cross-elasticity of demand." See Times-Picayune Publishing Co. v. United States, 345 U.S. 594, 612 n.31 (1953) ; cf. United States v. E. I. du Pont de Nemours \& Co., 118 F. Supp. 41, 196-97 (D. Del. 1953).

124. See Effective Competition, supra note 5 , at $12,14$.

125. The concept of workable or effective competition "does not provide a standard of legality under any of the antitrust laws." ATr'x GEn. Consr. Rep. 316. See also Dirlam \& KaHin, op. cit. supra note 3, at 15; Kahn, Standards For Antitrust Policy, 67 Harv. L. Rev. 28, 41 (1953). For, as Carlston put it, "We desire a workable antitrust law as well as workable competition." Carlston, Antitrust Policy: A Problem in Statecraft, 60 YALE L.J. 1073, 1089 (1951). 
contracts should have been excluded. The workability of competition is at best a nebulous concept. ${ }^{126}$ And workable competition is a norm, not a goal: the goal of the antitrust laws is more-workable competition. ${ }^{127}$ If competition in a market is not workable, competitive injury is more likely to follow from questionable practices. ${ }^{12 S}$ But once a likelihood of injury is shown, the fact that an exclusive dealer was unsuccessful in eliminating his competitors (or even gaining on them $)^{129}$ would seem to be entirely irrelevant..$^{130}$

\section{Tying Arrangements}

In Insto-Gas Corp. the FTC remanded an initial cease and desist order because the record failed to give "comparative market data" from which a likelihood of substantial competitive injury might be inferred. ${ }^{131}$ Insto-Gas, a firm with aggregate annual sales of $\$ 800,000$, competes with other firms in the distribution of propane gas, metal cylinders containing propane gas, and other appliances used with them. ${ }^{132}$ It leases its cylinders only to dealers who contract to refill them with Insto-Gas and to use its appliances. ${ }^{133}$ Its business is nationwide, although confined to a limited line of propane gas products. ${ }^{134}$ No evidence of market shares was introduced..$^{135}$

126. Mason has aptly stated that "there are as many definitions of 'effective' or 'workable' competition as there are 'effective' or 'workable' economists." Mason, The New Competition, 43 Yale Rev. 37, 48 (1953). See the conflicting viewpoints as to the meaning of "workable" competition cited and analyzed in Loevinger, Antitrust and The New Economics, 37 MInn. L. Rev. 505, 528-38 (1953); Markham, An Alternative Approach to the Concept of Workable Competition, 40 Axr. EcoN. REv. 349 (1950); Stocking, supra note 121, at 1107-10. See notes 69-71 supra.

127. Att'y Gen. Comm. Rep. 316; cf. Dirlani \& KaHn, op. cit. supra note 3, at 3-16; Adams, The "Rule of Reason": Warkable Competition or Workable Monopoly?, 63 YaLE L.J. 34S, 366 (1954); Kahn, stupra note 111, at 294, 295.

128. Dirlam \& Kann, op. cit. supra note 3, at 38; cf. Pillsbury Mills, Inc., Docket No. 6000, 3 CCH Trade Reg. Rep. đ 11582 (FTC Dec. 28, 1953); Harley-Davidson Motor Co., Docket No. 5968, 3 id. \ 2510S (FTC July 7, 1954).

129. See note 107 supra.

130. United States v. Standard Oil Co., 78 F. Supp. 850, 863-64 (S.D. Cal. 1948), aff'd, 337 U.S. 293, 308-10 (1949) ; Revlon Products Corp., Docket No. 5685, 3 CCH TRADE REg. REP. I 25249 (FTC Nov. 22, 1954) (denying motion to reopen).

131. Docket No. 5851, 3 CCH TRAde REg. Rep. $\int 25188$ (FTC Oct. 21, 1954).

132. Insto-Gas sells two to three million pounds of propane gas annually, either directly to the user or through 200 dealers with whom it has entered tying contracts. Id. at p. 35388; see Insto-Gas Corp., Initial Decision at 3; Insto-Gas Record at 232, 244.

133. Insto-Gas has 80,000 cylinders outstanding on 11,000 separate leases. Initial Decision at 3; Record at 230, 243. Instead of refilling the cylinders (the "tying" product) when they become empty, dealers take the empty cylinder and give the user another cylinder, already filled with Insto-Gas, Initial Decision at 4.

134. Insto-Gas Corp., Docket No. 5851, 3 CCH TRADE REg. Rep. ff 25188, at 35388 (FTC Oct. 21, 1954). Propane gas is used for a number of purposes other than torching. Respondent asserted that its sales represented only $0.03 \%$ of the national sales of propane. Id. at p. 35340. But the FTC felt unable to decide whether this contention was even "relevant," because "the record does not clearly reveal in just what line of commerce competition is allegedly restrained." Ibid. Cf. note 122 supra.

135. "There is nothing to indicate respondent's relative size in the industry and no 
The FTC stated that it would have to apply "legal doctrine to a factual vacuum" to proscribe the tying contracts on this record..$^{136}$ Counsel had failed to define the market for the tied or tying product, and had failed to show what part of Insto-Gas' $\$ 800,000$ sales was attributable to the tying contracts. ${ }^{137}$ The total sales, given in terms of market fractions, would have been significant if they had shown that the seller was "dominant" in the tying market; the volume of sales under the contracts would have been significant if it had indicated the restraint of a substantial amount of commerce in the market for the product tied. ${ }^{138}$ For the FTC expressly adopted the TimesPicayune standard: that tying contracts were illegal whenever the seller is dominant in the tying market or there is a likelihood of substantial restraint in the market tied..$^{139}$ But the dominance or substantial restraint must be demonstrated, rather than assumed.140 And both "dominance" and "substantial" must be defined in terms of a relevant market. ${ }^{141}$

However, the "new" FTC should not equate the "dominance" necessary to illegalize the use of tying contracts under section 3 of the Clayton Act, with the "dominance" necessary to find monopolization under section 2 of the Sherman Act. ${ }^{142}$ For the Clayton Act was aimed at eliminating injury to competition in its incipient stage. ${ }^{143}$ The essence of the illegality of a tying contract is the wielding of market power to foreclose competitors from access to market outlets. ${ }^{144}$ If a seller has enough market control to force a sizeable number of the dealers in the market to enter tying contracts with him, he should be deemed prima facie to have shown sufficient "dominance" to justify a cease and desist order. ${ }^{145}$

information concerning the number, or competitive standing, of competitors." Insto-Gas Corp., supra note 134, at p. 35399.

136. Ibid.

137. Ibid.

138. See notes $94-96$ supra.

139. Insto-Gas Corp., Docket No. 5851, 3 CCH Trade Reg. Rep. If 25188, at 35399 (FTC Oct. 21, 1954).

140. Ibid.

141. See notes 120-23 supra and accompanying text.

142. See Norwood, op. cit. supra note 94, at 113; MILLER, op. cit. supra note 94, at 199; Note, 49 Colurs. L. Rev. 241, 246 (1949). But see Times-Picayune Publishing Co. v. United States, 345 U.S. 594, 611-12 (1953). Of course, Times-Picaynune was tried under the Sherman Act rather than the Clayton Act, and that may have had some influence upon the tests of dominance the Court used. See id. at 609. At any rate, the Court held that $40 \%$ of the market was not sufficient to constitute dominance. Id. at 611-12. And its method of arriving at the figure of $40 \%$ warrants sharp criticism. See Kahn, supra note 1.11, at 326; Note, 63 YALE L.J. 389, 390-91 (1954).

143. See legislative history cited in Schwartz, supra note 88, at 21 n.40; Times-Picayune Publishing Co. v. United States, 345 U.S. 594, 609-10 (1953); Standard Oil Co. v. United States, 337 U.S. 293, 311-13 (1949).

144. Times-Picayune Publishing Co. v. United States, 345 U.S. 594, 611 (1953); Insto-Gas Corp., Docket No. 5851, 3 CCH Trade REG. REp. \I 25188, at 35339 (FTC Oct. 21, 1954) ; ATT'y GEN. CoMm. REp. 144.

145. See authorities cited in note 142 supra. 


\section{Enforcenent of section 7 of the Clayton ACt by the "New" FTC}

Section 7 of the Clayton Act provides that "no corporation engaged in commerce shall acquire, directly or indirectly, the whole or any part of the stock or ... assets of another corporation ... where in any line of commerce in any section of the country, the effect of such acquisition may be substantially to lessen competition, or to tend to create a monopoly."146 Recently there has been a widespread wave of mergers and a trend towards agglomerate commercial growth. ${ }^{147}$ In the light of this trend, the merger is probably the greatest contemporary threat to the ideal of a competitive market. For the acquiring firm usually eliminates competitors as it expands its own facilities. ${ }^{148}$ In 1950 Congress amended section 7 to assure a maverick judiciary that mergers tending to reduce the vigor of competition in any market should be restrained before they actually did reduce competition. ${ }^{149}$ But the Justice De-

146. 64 Stat. 1125 (1950) (Celler Anti-Merger Act), 15 U.S.C. $\$ 18$ (1952), amending 38 STAT. 731 (1914).

The "line of commerce" involved need not constitute a major portion of the business of either the acquiring or the acquired company. S. REp. No. 1775, 81st Cong., $2 \mathrm{~d}$ Sess. 5 (1950) (hereinafter cited as S. REP. No. 1775) ; MERGER REPORT 166. Furthermore, acquisition of part of the stock or assets of a firm is sufficient. Id. at 151; see Hamilton Watch Co. v. Benrus Watch Co., 114 F. Supp. 307 (D. Conn. 1953) ; Note, 63 Yale L.J. 233 (1953). Furthermore, the Act probably covers the acquisition of patents. See Barnes, Economic Isstes in the Regulation of Acquisitions \& Mergers, 14 O\#то ST. L.J. 279, 291 (1953). And since there is virtually no difference between a merger and a long-term lease of assets, $c f$. Note, 64 YaLE L.J. 282, $289 \mathrm{n} .48$ (1954), the Act should also apply to leasing arrangements, including purchase of an existing lease. Cf. MERGER REPORT 57.

147. Commercial mergers and acquisitions are three times as numerous today as they were in 1948. MERGER REPORT cc. 2, 3, summarized in FTC Showes Its Scorecard, Business Week, May 21, 1955, p. 33. There were 1,773 mergers in the fields of manufacturing and mining between 1948 and 1954. MERGER REPORT 23. The impressive fact is that $45 \%$ of these mergers involved a firm with assets already exceeding $\$ 10$ million. Id. at 31 . In the aggregate these firms accounted for $65.5 \%$ of the merger wave. Id. at 23. Firms with assets of $\$ 1$ million or less accounted for only $8 \%$ of the mergers. Ibid.

Five reasons were generally given for the mergers: 1) to increase capacity to serve presently-supplied markets $(40 \%) ; 2)$ to increase capacity to serve new markets $(10 \%)$; $3)$ to diversify the line of products $(25 \%) ; 4)$ to assure supplies by backward vertical integration $(12.5 \%) ; 5)$ to assure market outlets by forward vertical integration $(10 \%)$. Id. at 50-52.

148. "Every acquisition of existing hitherto independently owned and managed properties results in the elimination of any direct competition which may have existed between the parties, as well as forestalls any potential competition which might have developed later between the two had the acquirer constructed his own new facilities." MERGER REPORT 131. Thus, the effect of the merger is not simply an expansion of the acquiring firm's facilities. "If he builds he creates additional capacity and competition; if he buys he reaps not only the advantage of increasing his capacity but acquires the market previously served by a competitor." Howrey, Statement Before the Subcommittee on Antitrust and Monopoly of the Senate Committee on the Judiciary 8 (1955) (mimeograph). See MERGER REPORT 111.

149. Old $\$ 7$ was "emasculated by an unsympathetic judiciary." Note, 63 YALE L.J. 233 (1953). Narrow judicial interpretation had created a Sherman Act standard of 
partment and the Commission have not been quick to use the teeth Congress put in the amended merger law 150

In Pillsbury Mills, Inc., the "new" FTC issued a carefully written opinion that was clearly intended to be a "guidepost" to future anti-merger policy. ${ }^{101}$ Pillsbury was the nation's second largest miller of flour products. ${ }^{152}$ It achieved its ranking position largely by acquiring other firms. ${ }^{153}$ In 1951 it acquired Ballard \& Ballard, and in 1952 it acquired Duff Baking Mix. ${ }^{154}$ Both firms were in substantial competition with Pillsbury in the Southeast urban market, ${ }^{155}$ and the acquisitions fortified Pillsbury's already strong position in

illegality for Clayton Act mergers. See, e.g., Pennsylvania R.R. v. ICC, 66 F.2d 37 (3d Cir. 1933), aff'd by an equally divided Court, 291 U.S. 651 (1934).

Congress passed the Celler Anti-Merger Act, 64 STAT. 1125 (1950), 15 U.S.C. $\S 18$ (1952), to make it clear that $\S 7$ was "not intended to revert to the Sherman Act test. The intent here, as in other parts of the Clayton Act, is to cope with monopolistic tendencies in their incipiency...." S. REp. No. 1775, supra note 146, at 4-5. See also H.R. REP. No. 1191, 81st Cong., 1st Sess. 8 (1950) (hereinafter cited as H.R. Rep. No. 1191) ; AtT'Y Gen. Commr. Rep. 117.

150. The Commission has considered only one anti-merger case since the 1950 Amendment. Pillsbury Mills, Inc., Docket No. 6000, 3 CCH TRADE REG. REP. $\{11582$ (FTC Dec. 28, 1953). Another is pending. Crown-Zellerbach Corp., Docket No. 6180. The MERgER REPORT, based on information in FTC files, indicates that 9 firms acquired 10 or more firms between 1948 and 1954. Id. at 29. Yet, no complaint has issued against any of these firms, many of whom are market leaders (minimum assets, $\$ 49$ million; average for the 9 firms, $\$ 215.9$ million). Thus far the Department of Justice has been no more aggressive. See statement of Judge Stanley N. Barnes, Assistant Attorney General. Hearings Before the Select Committee on Small Business to Consider the Att'y Gen. Comm. Rep., 84th Cong., 1st Sess. 3 (1955).

151. Pillsbury Mills, Inc., Docket No. 6000, 3 CCH Trade Reg. Rep. fi 11582 (FTC Dec. 28, 1953).

152. It was also second nationally in sales of family flour and flour-based mixes. Ibid.

153. It had increased its sales from $\$ 47$ million to $\$ 224.5$ million between 1940 and 1951 , a period in which it had acquired many other firms in the industry. Ibid.

154. Duff had been the fifth largest seller of mixes in the national and southeastern markets. Pillsbury paid $\$ 2$ million for Duff.

Ballard \& Ballard ranked third in sales of mixes and family flour in the southeastern market. It had been an "important factor in the competitive market." Pillsbury acquired Ballard \& Ballard for $\$ 5$ million. Ibid.

155. See note 154 supra.

The FTC accepted counsel's argument that only the urban market was the area of "effective competition" for the firms involved in the acquisition. See Appellate Brief for FTC, Pillsbury Mills, Inc., pp. 4, 37. Figures therefore gertain to that area, and are based upon market surveys and best estimates prepared by Pillsbury in an attempt to convince the Commission that a formal proceeding would not be necessary. See FTC Reply Brief to Respondent's Opposing Brief, pp. 2-3. Respondent's Opposing Brief had argued that the figures were only estimates, and did not accurately depict market realities. $I d$. at 41 . But Pillsbury refused to respond to a subpoena dicces tecum to produce more accurate information. FTC Reply Brief, supra, pp. 2-3. For this reason, and because no completely accurate data existed for the market (and could not be compiled at a reasonable cost), the FTC overruled the examiner's finding that the evidence was unreliable. Pillsbury Mills, Co., Docket No. 6000, 3 CCH TRAde Reg. REP. $\uparrow 11582$ (FTC Dec. 28, 1953). 
that market. ${ }^{150}$ Furthermore, the acquisitions occurred in an industry heading rapidly towards oligopolistic concentration. ${ }^{157}$ And they unquestionably hastened that drift. ${ }^{15 s}$ The FTC concluded that the evidence established a prima facie case of illegality under section 7 of the Clayton Act.159

More important than the holding, however, is Chairman Howrey's extensive discussion of the standards the FTC will follow in its future antimerger cases. The "new" FTC's test of illegality under section 7 will be "somewhere in between" the Sherman Act test of actual injury to competition and a per se test of quantitative substantiality. ${ }^{160}$ The scope of the inquiry will be as wide as all the economic factors, as in a Sherman Act case, but the standard of proof will be less rigid. ${ }^{161}$ How much less will be worked out "case by case."102

The substantiality of the sales and market shares of the merging firms will be important evidentiary factors. ${ }^{163}$ However, they must be buttressed with evidence of the competitive structure of the industry and markets involved, so

156. By acquiring Ballard \& Ballard, Pillsbury's share of the southeastern market for bakery flour rose from second $(3.6 \%)$ to first $(8.1 \%)$ place and its sales increased 40\%. In mixes, its sales increased $78 \%$ and it boosted its first place margin from $22 \%$ to $45 \%$. In family flour its sales rocketed $154 \%$ as it rose from fifth $(4.9 \%)$ to second $(8.5 \%)$. And by acquiring Duff, Pillsbury's national position in mixes rose from second $(16 \%)$ to first $(23 \%)$. Ibid. The full significance of the increases lies in the fact that Pillsbury's market shares increased more than the combined shares it and the acquired firms had enjoyed before the acquisition.

157. The flour milling industry is "saturated." Only large millers can increase or even maintain their sales. From 1945 to 1951 the total output capacity of the industry decreased, but the relative and absolute output capacity of the ten top mills increased. This was due largely (68\%) to mergers. Further, largely due to mergers, the total number of mills has decreased from 11,691 in 1909 to 1,799 in 1951. And there has been no new entry in the southeastern market in recent years. Ibid.

158. Evidence of two types was introduced to substantiate this point:

1) Whereas there had been price competition between Pillsbury and Ballard \& Ballard before the acquisition, their prices were identical afterwards. See Pillsbury Mills Record at 290, 379, Appendix Tables pp. 14-17.

2) The industrial pattern was being significantly altered. The market was composed of three types of sellers: large ones like Pillsbury or General Mills; small rural millers who could not compete with the large firms in the urban markets, even at a lower price; and middle-sized firms like Ballard \& Ballard or Duff, who were big enough so that the large firms could not ignore them, but small enough to be sensitive to the lower-priced rural firms. By taking the middle-sized firms off the market, competitive contact between the small and large firms was removed. FTC Appellate Brief, p. 48.

159. Pillsbury Mills, Inc., Docket No. 6000, 3 CCH Trade REg. Rep. I 11582 (FTC Dec. 28,1953 ). The case was remanded to an examiner to permit respondent to introduce rebutting evidence.

160. Ibid.

161. Ibid.

162. Ibid. The Commission pointed to United States v. Columbia Steel Co., 334 U.S. 495 (1948), as a concrete example of a case where a merger, legal under the Sherman Act, would be illegal under amended $\$ 7$ of the Clayton Act. Pillsbury Mills, Inc., Docket No. 6000, 3 CCH Trade Reg. Rep. If 11582 (FTC Dec. 28, 1953).

163. Ibid. 
that the Commission may evaluate the impact of the acquisition within a structural context. ${ }^{164}$ Proof that competitors are foreclosed from access to a substantial share of the market might be sufficient to permit an inference of competitive injury under section 3 , because that section was enacted primarily to protect competitors' access to market outlets. ${ }^{165}$ But the Commission stated that the primary purpose of section 7 is to protect the pattern of competition. ${ }^{100}$ The FTC will look to the types of effects that Congress stated were symptomatic of competitive injury: 1) the elimination of a firm which had been a substantial competitive force in the market;2) an increase in the relative size of the acquiring firm that tended to give it a decisive advantage over its competitors; 3 ) an undue reduction in the number of competing firms; or 4) the establishment of relations between buyers and sellers which deprive their competitors of a fair opportunity to compete with them. ${ }^{\mathbf{1 6 7}}$ But no single characteristic of an acquisition will be sufficient to permit an inference of its probable effect on competition in general. ${ }^{168}$

The FTC was not justified in making the blanket statement, without authority and without qualification, that section 7 was directed only towards preventing adverse changes in the pattern of competition "in general," and not towards protecting competitors from the foreclosure of substantial shares of relevant markets. ${ }^{169}$ Competition is not a thing; it cannot be injured;

164. The FTC flatly stated that it would be insufficient to show that "an acquiring and acquired company together control a substantial amount of sales, or that a substantial portion of commerce is affected." Ibid. "Analysis of the competitive effects of an acquisition should begin, we believe, with the relevant facts concerning the competitive pattern of the industry as a whole and its markets. ..." (Emphasis added.) From there counsel should introduce evidence of the merger and its changes on the "character of the competition in the markets concerned." Ibid.

This does not seem to be dictum. Counsel had argued that it had established a prima facie case of illegality by showing that respondent was a leading factor in the relevant market, and that the acquired companies had done a substantial amount of business. FTC Appellate Brief, p. 36. The FTC rejected this argument without explicit mention, and rested its decision on the structural evidence counsel had produced in case their major argument were rejected. See Pillsbury Mills, Inc., Docket No. 6000, 3 CCH TRAdE REg. REP. $\| 11582$ (FTC Dec. 28, 1953).

165. Ibid.

166. Ibid.

167. Ibid. The Commission relied upon H.R. REP. No. 1191, supra note 149, at 8, where these tests were explicitly adopted by the House Committee.

168. Pillsbury Mills, Inc., Docket No. 6000, 3 CCH Trade Reg. Rep. If 11582 (FTC Dec. 28, 1953).

169. Congress intended $\S 7$ 's standards of legality to be "similar to those which the courts have applied in interpreting the same language as used in other sections of the Clayton Act." H.R. ReP. No. 1191, supra note 149, at 8; see S. REP. No. 1775, supra note 146, at 4-5; Note, 63 Yale L.J. 233, 238-40 (1953); Note, 52 Coluar. L. Rev. 766 (1952); Note, 64 HARv. L. REv. 1212 (1951). See also Hearings Before the Subcommittec on H.R. 2734 of the Sente Committee on the Judiciary, 81st Cong., 1st and 2d Sess. (194950) (hereinafter cited as Hearings on H.R. 2734), in which the Subcommittee repeatedly referred to the standard of Standard Stations. Hearings on H.R. 2734, supra, at 31-32, 53, 144, 163, 169-71, 200. But see MERger Report 162. 
competitors can. The real issue is how much evidence of what sorts of injury to which competitors-present or potential-must be presented in order to establish the requisite likelihood of competitive injury. ${ }^{170}$ The types of evidence that Congress pinpointed as symptomatic of injury to competition are crucial. ${ }^{171}$ But evidence of each type is not necessary in order to establish a prima facie case of illegality. ${ }^{172}$

The FTC must further analyze the different types of mergers and the different types of injuries to which they expose competitors, rather than assume that injury must be shown to competition "in general." There are three functionally distinct types of mergers: horizontal, vertical and conglomerate. ${ }^{173}$ Each may have a different impact on competition. ${ }^{174}$ The types of evidence required should vary with the type of merger. ${ }^{175}$ The amounts of evidence

170. "Competition" is the result of a large number of firms competing with each other and unable to prevent still others from entering the market to compete with them. Practices that reduce the number of competitors, or impede their ability to compete with larger firms, must, by definition, tend to lessen "competition." If a substantial share of competitors are disadvantaged, if any are substantially disadvantaged, or if entry is impaired, the potential injury to "competition" that $\$ 7$ proscribes is shown. See notes 17176 infra and accompanying text.

171. See note 167 supra and accompanying text.

172. See AtT'y Gen. Conm. Rep. 122; Note, 63 Yale L.J. 233, 241 n.39 (1953). But sce Barnes, supra note 146, at 300, who feels that unless each type of test is used it will not be possible to decide on an empirical basis which tests really are most appropriate to different types of mergers.

The purpose of amending $\S 7$ was to forestall mergers that might lessen competition before they could actually injure competition. See note 149 supra. Thus mergers that were not substantial would be illegal if they were a part of a cumulative drift towards lessened competition. S. REP. No. 1775, supra note 146, at 7 ; H.R. REP. No. 1191, supra note 149, at 6; Hearings on H.R. 2734, supra note 169, at 131, 135-38. And the scope of the market could be any line of commerce, whether or not it was a large part of the business of any firms involved. See note 146 supra. Thus, it would seem only consistent to conclude that whenever it is shown that one of the sorts of injuries which Congress sought to avoid, see note 167 supra, is likely to occur in one of the relevant markets, the merger would be illegal if further explanatory evidence were not introduced. But the introduction of explanatory evidence should be the burden of the respondent. See notes $80-83$ supra and accompanying text.

173. Of recent mergers, about half have been horizontal, while about a quarter each have been vertical and conglomerate. See note 147 supra. The differences are defined in text at notes 177, 185, 195 infra. See also Merger Report 168; Burns, The Decline of CONipetition 418 (1936). Congress recognized the three different types of mergers and meant each to come within the amended Act whenever likely to lessen competition. See H.R. REP. No. 1191, supra note 149, at 8; MERGER REPORT 168; Barnes, supra note 146, at 281 . Horizontal and vertical mergers are the more likely to lessen competition. See Atr'y Gen. Conim. Rep. 122.

174. Atr'y Gen. Connr. Rep. 122; Barnes, supra note 146, at 293; cf. Merger RePORT 173; Schwartz, The Impact of Standard Oil of California v. United States on the Standard of Legality Under the Clayton Act, 98 U. PA. L. Rev. 10, 31 (1949).

175. See Atr'Y Gen. Comsr. Rep. 122; Barnes, supra note 146, at 299, 300; Note, 63 YALE L.J. 233, 241 n.39 (1953). 
required should also vary accordingly, but always in line with Congress' mandate to proscribe anti-competitive mergers in their incipiency. ${ }^{176}$

A horizontal merger combines firms that were in direct competition with each other. ${ }^{177}$ This necessarily reduces the number of competitors in the market. Congress has stated that an "undue" reduction in the number of competitors is indicative of a merger's illegality. ${ }^{178}$ What is an "undue" reduction in the "number" of competitors should depend upon the market shares of the merging firms. For ordinarily, the quality of the competition in a market varies directly with the number of competitors, and ease of entry varies inversely with their size. ${ }^{179}$ By merging with a competitor rather than building new facilities, the acquiring firm reduces the number of competitors at the same time as it expands its size. ${ }^{180}$ Therefore if the merging firms, taken together, did a "substantial" share of the business in the market, their merger should be prima facie illegal. ${ }^{181}$

This standard might preclude larger firms from merging. ${ }^{182}$ However, those firms can accommodate any genuine need for expansion without taking competitors off the market. When they acquire competitors the acquisition

176. See notes $149,172-73$ supra.

177. See note 173 supra.

178. See note 167 supra and accompanying text.

179. See Felliner, Conpetition Among the Few (1949). Stocking \& Watkins, Monopoly and Free ENTERprise (1951); Bowman, Toward Less Monopoly, 101 U. PA. L. Rev. 577, 631-41 (1953) ; Note, 63 YALE L.J. 233, 240 (1953).

180. See note 148 supra and authorities there cited. See also Clark, The Oricntation of Antitrust Policy, 40 Arr. Econ. Rev. 93, 96-97 (Supp. 1950); Kahn, A Legal and Economic Appraisal of the 'New' Sherman and Clayton Acts, 63 YALE L.J. 293, 342-43 (1954). Moreover, large firms generally have greater capital reserves, and are likely to "pay a premium for eliminating competition" through acquisition. See Schwartz, supra note 174 , at 31 .

181. See Note, 63 YALE L.J. 233, $239-40$ (1953). In a saturated industry, or one with high costs of entry, a figure well below $10 \%$ might be "substantial." See notes 79-80, 120-21 supra and accompanying text; text following note 183 infra. Ordinarily, however, a merger of firms controlling $10 \%$ of a market's business would be likely to have a substantially adverse effect upon competition in the market. See Bain, Workable Competition in Oligopoly: Theoretical Considerations and Some Empirical Evidence, 40 AM. Econ. Rev. 35, 37 (Supp. 1950) ; Bowman, supra note 179, at 638-41.; Note, 63 YALE L.J. 233, 241 n.39 (1953).

Furthermore, it might be found that the reduction is "undue" because of foreclosures of market access to dealers at different levels of processing. If the merging firms had been engaged in price (or product) competition before the merger, their customers were given live market alternatives. But if the merger resulted in a one-priced product for both firms (as it did in Pillsbury, see note 158 supra), customers are foreclosed from market alternatives. And suppliers are in the same position if the two firms consolidate their buying to achieve volume discounts. If alternatives are substantially lessened by the merger, even in other markets, it would seem to fit within $\S 7$ proscriptions. See notes 191-92 infra and accompanying text. Thus, the "substantiality" may be defined in terms of a different (and possibly smaller) market.

182. The legislative history tends to indicate that Congress had this sort of ban in mind. See S. REP. No. 1775, supra note 146, at 7; H.R. REP. No. 1191, supra note 149, at 6 ; Hearings on H.R. 2734, supra note 169 , at 131, 135-38. 
ordinarily "may" injure competition, and the firms should have the burden of showing that "substantial," in the particular industry, is not equivalent to "undue." Structural and behavioral evidence tending to show that a merger does not endanger freedom of entry might be admissible to rebut a prima facie case once established. ${ }^{183}$ But aside from FTC counsel's initial description of the relevant markets, the burden of introducing and proving such evidence should rest on the merging firm. ${ }^{184}$ Counsel should, of course, be free to introduce structural and behavioral evidence to show that comparatively small market shares are, in the particular market setting, nevertheless "substantial."

A vertical merger integrates an acquiring firm with one to which it sold its products (forward vertical integration) or from whom it bought the raw materials necessary to process its products (backward vertical integration)..$^{185}$ These mergers may lessen competition in the markets of either the acquiring or the acquired firms. ${ }^{186}$

At the market level of the acquired firm vertical integration is a permanent, proprietary form of exclusive dealing and tying arrangement. ${ }^{187}$ Firms integrate vertically in order to assure themselves of a source of supply or a market outlet, ${ }^{18 s}$ and they ordinarily will deal exclusively with the channel they have acquired. ${ }^{150}$ They could accomplish these same results by building

183. See Merger Report 135; Barnes, supra note 146, at 291; Schwartz, supra note 174, at 32; Howrey, Statement Before the Subcommittee on Antitrust and Monopoly of the Senate Committee on the Judiciary 10 (1955) (mimeograph). Of course, in some instances the market shares involved may be so substantial that evidence of free entry would be superfluous, $C$. notes 122,181 supra.

184. See notes $\$ 1-83$ supra and accompanying text.

185. See note 173 sitpra. Of $22.5 \%$ of recent mergers that were vertical, $12.5 \%$ were "backward," i.e., to assure supplies.

186. Barnes, supra note 146, at 292, 299 ; of. EDwards, op. cit. supra note 71, at 17175; DrmLam \& KaHN, op. cit. supra note 3, at 141-50. However, it should not be necessary to look to injury at each level once injury is shown to be likely at either. See notes 17273 sitpra and accompanying text.

187. See Atr'y Gen. Conrm. Rep. 28, 29; DiRladx \& KaHn, op. cit. supra note 3, at 173; Kahn, supra note 180, at 344; McLaren, Related Problens of 'Requirements' Contracts and Acquisitions in Vertical Integration Under the Antitrust Lazes, 45 ILL. L. REv. 141, 142-43 (1950). Cf. United States v. Columbia Steel Co., 334 U.S. 495, 523 (1948). Kahn, sukra, at 345, suggests, however, that if a frm "is willing to assume the risks of ownership, it must be permitted a wider measure of control than where it is contracting with independent parties."

188. ATT'Y GEN. Cosm. Rep. 122; Rostow \& Sachs, Entry Into the Oil Refining Business: Vcrtical Intcgration Re-examined, 61 Y ALE L.J. 856, 870 (1952); cf. Barnes, supia note 146, at 292; Schwartz, supra note 174, at 31.

189. See United States v. Columbia Steel Co., 334 U.S. 495, 523 (1947) ; McLaren, sitpra note 187, at 158; Rostow \& Sachs, supra note 18S, at 877 . This is to be expected, of course, for the integration will ordinarily lower the aggregate cost. See id. at 878; Kahn, supra note 180, at 343; Spengler, Vertical Integration and Antitrust Policy, $58 \mathrm{~J}$. PoL. ECon. 347-52 (1950). Cost savings are a major reason for integrating. See Adelman, Intcyration and Public Policy, 63 HARv. L. Rev. 27, 40, 47 (1949).

Of course, the acquiring firm's needs (backward integration) seldom will mesh perfuctly with the acquired firm's output. Thus, to some extent, the integrated firm will deal with competitors or waste capacity. Id. at 44 . 
new outlets or supply channels, which would increase competition in the next adjacent market. ${ }^{190}$ But when an enterprise purchases an existing channel it forecloses competitors of the acquired firm from supplies or outlets to the extent that they bought from the acquiring firm (in a forward integration) or sold to it (in a backward integration). ${ }^{191}$ If the merger foreclosed these competitors from access to a "substantial" share of the relevant market, it should be prima facie illegal-just as in section 3 cases. The type of injury is virtually indistinguishable except that the merger, being permanent, creates a more complete foreclosure than would an exclusive dealing or tying arrangement. ${ }^{192}$

Even if the acquiring firm continues to buy from or sell to former competitors of the acquired branch, the merger may lessen competition at either market level. If the acquiring firm is sufficiently dominant in its own market that former competitors of its acquired firm must deal with it, the acquiring firm may be able to put them at its mercy by juggling profit margins and instituting an inter-market "squeeze." For when a firm is integrated, it is irrelevant to it at which stage of its operations it formally enters its profits. Thus, in a forward integration, it can set an arbitrarily high price to competitors of its acquired branch. This would squeeze those competitors, because they must compete in price with the acquired branch at resale. Their profit margin is sliced, while the integrated firm may average its correspondingly lower profit in the resale market with the higher profit it is thereby enabled to make in the processing market. ${ }^{193}$ The same competitive squeeze may be applied at the level of the acquiring firm if, by the acquisition, it attains or is on its way to attaining dominance in an adjacent market to which its competitors must sell or from which they must buy. Of course, a firm must have considerably more than a "substantial" share of a market in order to institute a squeeze. It must have effective leadership in an imperfect market. However, "monopoly" size is probably unnecessary. And it should not be necessary to show an actual intent to squeeze. There is sufficient coercive power latent in such a situation to make the likelihood of real competition in either market virtually nil..$^{194}$

190. See notes 148,180 supra.

191. See ChaMraerlin, op. cit. supra note 49, at 122; McLaren, supra note 187 , at 158. Moreover, the foreclosures may extend beyond the immediately merging firms, for competitors of each may find it necessary to integrate "defensively" in order to keep their own positions. See Rostow \& Sachs, supra note 188, at 878-79; Hale, Vertical Inttegration, 49 CoLuM. L. REv. 921, 936-37, 949-52 (1949).

192. See McLaren, supra note 187 , at 141 ; notes $92-93,97-99,110-13$ supra and accompanying text.

193. See United States v. Aluminum Co., 148 F.2d 416, 433-45 (2d Cir. 1945), especially approved, American Tobacco Co. v. United States, 328 U.S. 781,813 (1946); DirLaM \& KAHN, op. cit. supra note 3, at 141-50; EdWARDs, op. cit. supra note 71, at 171-75; Adelman, supra note 189, at 44; Barnes, supra note 146, at 299. The same sort of squeeze may, of course, be worked in a backward integration.

194. Mavericks would then exist, if at all, at the dominant firm's pleasure. See authorities cited note 193 supra. 
"Conglomerate" mergers combine firms with no previous competitive relationship. ${ }^{105}$ They are far less likely to injure competition. The desire to diversify is commercially sound, and it is unwise to prevent firms from entering new markets without good reason. ${ }^{196}$ However, the very ability of some large firms to utilize their size and market leverage to absorb losses and acquire price favors may make it unwise to permit them to expand by acquisition into other imperfect markets. ${ }^{197}$ In these cases it is quite true that no single characteristic can earmark the competitive probabilities of a merger $;^{198}$ the FTC should inquire into all the indicia of illegality which Congress enumerated. ${ }^{100}$ Further consideration should center upon the susceptibility of the markets to monopolistic leverage, and upon the anti-competitive records of the firms. ${ }^{200}$

\section{Enforcement of the Robinson-Patman Act by the "New” FTC}

Section 2(a) of the Clayton Act, as amended by the Robinson-Patman Act, forbids a seller to discriminate in price by selling like commodities to different customers at different prices, whenever the effect of that discrimination "may be substantially to lessen competition or tend to create a monopoly in any line of commerce, or to injure, destroy or prevent competition with any person who either grants or knowingly receives the benefits of such discrimination, or with the customers of either of them. ..."201 The policy of the Act is to give small businessmen a chance to compete on equal terms with larger firms who are not more efficient: to recognize economies of size, but not economies of leverage and coercion.202 The Act also makes it illegal for a buyer "know-

195. See note 173 supra.

196. See Dirlam \& KAHN, op. cit. supra note 3, at 141 ; Kahn, Standards For Antitrust Policy, 67 Harv. L. Rev. 28, 47 (1953); cf. United States v. Columbia Steel Co., 334 U.S. 495, 526 (1948).

197. See Edwarns, op. cit. supra note 71, at 108-17, 130; Merger Report 103; Quinn, Giant Business: Threat to Demrocracy 167, 200, $227-28$ (1953); Kahn, supra note 196 at 42.

198. See Atry Gen. Conm. Rep. 119; Barnes, supra note 146, at 299.

199. See note 167 supra and accompanying text.

200. See United States v. Swift \& Co., 286 U.S. 106, 116 (1932); United States v. Aluminum Co., 148 F.2d 416, 430 (2d Cir. 1945) ; Dirlan \& KAHN, op. cit. sulpra note 3, at 104; EDwaRDs, op. cit. supra note 71, at 159-67; cf. Schine Chain Theatres, Inc. v. United States, 334 U.S. 110, 119 (1948). Thus, although "intent" is not in issue, intent plus power may "be taken into account in arriving at a judgment as to the probable effects of an acquisition." MERger Report 159.

201. 49 Stat. 1526 (1936), 15 U.S.C. $\$ 13$ (1952), amending 38 Stat. 730 (1914). (Emphasis added.) The italicized language was added by the 1936 amendment, which was enacted primarily to counteract the discriminatory practices of chain stores by lowering the standard of injury required. See Rowe, Price Discrimination, Competition and Confusion: Another Look at Robinson-Patman, 60 YALE L.J. 929 (1951) ; Notes, 36 Colum. L. Rev. 1285 (1936), 50 HARv. L. Rev. 106 (1936).

202. The value of Robinson-Patman lies in "the assurance of equal opportunity and tair play which this bill gives to local independent business. ..." Statement of Congress- 
ingly" to accept a discrimination, ${ }^{203}$ but, in view of the Supreme Court's restrictive decision in Automatic Canteen, ${ }^{204}$ it is unlikely that the "new" FTC will even attempt to prosecute buyers. ${ }^{205}$

In actions against the seller, the injury alleged may be to competitors of the seller ("primary-line" competition) or to competitors of the buyer ("secondary-line" competition) or their customers. ${ }^{206}$ The FTC has the burden of proving the fact of discrimination and the likelihood of competitive injury. ${ }^{207}$ Sellers may defend absolutely by proving that price differences made only "due allowance" for differences in costs, ${ }^{208}$ or that the differences were made in good faith to meet an equally low price of a competitor. ${ }^{209}$

man Utterback, 80 Cong. Rec. 9416 (1936) ; see S. Rep. No. 1502, 74th Cong., 2d Sess. (1936) ; H.R. Rep. No. 2287, 74th Cong., 2d Sess. (1936) ; FTC v. Morton Salt Co., 334 U.S. 37, $42-43$ (1948). Economic studies indicate that price discrimination is usually based upon market leverage and buying power, rather than increasing economies of size. See EDwARDs, op. cit. supra note 71, at 161, and studies there cited. The FTC Chain Store Investigations, which led to the passage of Robinson-Patman, made it perfectly clear that this was true in chain store selling. See S. Doc. No. 4, 74th Cong., 1st Sess. passim (1934).

203. 49 STAT. 1526 (1936), 15 U.S.C. \& 13 (f) (1952). This subsection provides that "it shall be unlawful for any person engaged in commerce . . knowingly to induce or receive a discrimination in price which is prohibited by" subsection (a).

204. Automatic Canteen Co. v. FTC, 346 U.S. 61 (1953). In this ambiguous decision the Supreme Court apparently held that the FTC could not establish a prima facie case of illegality against a buyer simply by showing that he knowingly induced or received a price discrimination; rather, the FTC must come forward with evidence showing the buyer knew or should have known that the discrimination was illegal, i.e., not justified by differences in cost. Id. at 80 . See Note, 63 YALE L.J. 260 (1953).

205. Since Automatic Canteen, supra note 204, was decided, FTC decisions under $\$ 2(f)$ generally have been limited to dismissing complaints brought before the Cantean decision. See, e.g., Kroger Co., Docket No. 5991, 3 CCH TRADE REg. Rep. \} 1 1 5 1 3 \text { (FTC } Sept. 1953) ; Safeway Stores, Docket No. 5990, 3 id. \ 11474 (FTC Aug. 1953) ; Crown Zellerbach Corp., Docket No. 5421, 3 id. . 25352 (FTC Feb. 1955). However, it is still possible to obtain a conviction by showing a discrimination, proving it was not cost justified, and then proving the buyer knew or should have known it was not cost justified. Borden-Aicklen Auto Supply Co., Docket No. 5766, 3 id. đI 25071. (FTC May 1954) (refusal to dismiss complaint).

206. See text at note 201 supra; Austin, Price Discrimination and Related Proplems Under the Robinson-Patman Act 46 (1952); Comment, The Standard of Injury Applicable to Primary-Line Competition, 49 Nw. U.L. Rev. 209 (1954).

207. See Minneapolis-Honeywell Regulator Co. v. FTC, 191 F.2d 786, 789 (7th Cir. 1951), cert. denied for lateness in filing, 344 U.S. 206 (1952); but see S. H. MIoss, Inc. v. FTC, 148 F.2d 378, 379 (2d Cir.) (dictum), cert. denied, 326 U.S. 734 (1945). FTC v. Morton Salt Co., 334 U.S. 37 (1948), is often cited contra, but is ambiguous on the point. See note 211 infra.

208. Originally $\$ 2$ permitted price discrimination based upon quantity; RobinsonPatman significantly changed the section by proscribing all discounts that a seller could not prove were justified by actual cost savings. See FTC v. Morton Salt Co., 334 U.S. 37, 43 (1948); Goodyear Tire Co. v. FTC, 101 F.2d 620 (6th Cir.), cert. denied, 308 U.S. 557 (1939); Rowe, supra note 201, at 930; notes 48-61 supra and accompanying text.

Another important change is that any discount, even if justified by cost differences, may be disallowed or limited if the buyers benefited by it are so few as to make the dis- 
Recent FTC decisions in secondary-line cases seem consistent with the policy of the Robinson-Patman Act. In the Morton Salt case ${ }^{210}$ the Supreme Court held that a discrimination requiring one customer to pay more than his competitors, for like goods, necessarily lessened his ability to compete equally with them, so that the fact of discrimination alone is sufficient basis for the requisite inference of competitive injury. ${ }^{211}$ In the recent series of Auto Part cases ${ }^{212}$

count especially promotive of monopoly. 49 STAT. 1526 (1936), 15 U.S.C. $\$ 13$ (a) (1952). See Quantity Limit Rule 203-1 (Dec. 1951), 17 Fed. Reg. 113 (1952), 2 CCH TRADE REG. REP. $\uparrow 3611.01$ (1954). The principle of the quantity limit proviso is that "economies of mere size do not justify the risk of monopoly." Id. at p. 5385. See also S. REP. No. 1502, 74th Cong., 2d Sess. (1936) ; H.R. REP. No. 2287, 74th Cong., 2d Sess. (1936). The only quantity limit ever imposed by the FTC is now being challenged in the courts. See B.F. Goodrich Co. v. FTC, 208 F.2d 829 (D.C. Cir. 1953).

209. 49 STAT. 1526 (1936), 15 U.S.C. $\S 13($ b) (1952), provides that a seller may rebut a prima facie case of illegality by proving that his discrimination was "made in good faith to meet an equally low price of a competitor. ..." In Standard Oil Co. v. FTC, 340 U.S. 231 (1951), the Supreme Court held that such a defense was an absolute justification. But compare this decision, with id. at 251-67 (dissent), and with statement of Congressman Utterback, SO Cong. REc. 9418 (1936). Senators Kefauver and Patman have proposed amendments "reversing" Standard Oil, but Congress has not yet acted upon them. See N.Y. Times, March 29, 1953, pt. III, p. 1, col. 2; March 19, 1953, p. 47, col. 5 .

The limits of the "meeting competition" defense have been fairly well staked out in Supreme Court decisions. The discriminatory price must be in good faith and defensively responsive to an individual competitive situation. See Standard Oil Co. v. FTC, supra at 251 ; FTC v. Cement Institute, 333 U.S. 683, $721-25$ (1948) ; FTC v. Staley Mfg. Co., 324 U.S. 746, 754-56 (1945). These cases state that the cut price must be a departure from seller's pricing system rather than an integral part of it; that the discrimination must result from a reduction in one area to meet competition rather than a rise in an area where competition is not so keen; that the lowered price may not go below competitors' prices; and that the competitors' price that is thus met must be a legal price. The "new" FTC appears to have adopted these criteria in Niehoff \& Co., Docket No. 5768, $3 \mathrm{CCH}$ TRADE REg. Rep. ๆ 25467, at pp. 35582-83 (FTC May 1955); E. Edelmann \& Co., Docket No. 5770, 3 id. đ 25445 (FTC May 1955).

210. FTC v. Morton Salt Co., 334 U.S. 37 (1948).

211. Id. at 44. The Court held that the discrimination was "likely" to injure competition even though the amount was small, and salt constituted a minor part of the general inventory carried by the grocer-buyers. Their profit margin was small, and any discrimination would disadvantage them. Id. at 48, 49. The same standard applies in private treble-damage actions, for the discriminatorily high price is "an added business expense placed upon plaintiff and necessarily adversely affected the chances of plaintiff to survive the keen competition." Russelville Canning Co. v. American Can Co., 87 F. Supp. 484, 493 (W.D. Ark. 1949); see Chicago Sugar Co. v. American Sugar Refining Co., 176 F.2d 1, 7 (7th Cir. 1949), cert. denied, 338 U.S. 948 (1.950). These cases indicate that lack of injury is a positive defense. See Comment, 49 Nw. U.L. Rev. 197, 204 (1954). But see Minneapolis-Honeywell Regulator Co. v. FTC, 191 F.2d 786 (7th Cir. 1951), cert. denied for lateness in filing, 344 U.S. 206 (1952).

In the Honeywell case the court held that discriminations in the price of thermostats, to customers who manufactured boilers, was not sufficiently important to warrant a presumption of competitive disadvantage, despite an FTC finding that it would. $I d$. at 191 F.2d 790-91. It is not clear, however, whether the court found that there was not a prima facie case of injury or that it had been rebutted. At any rate, the decision appears to be 
the "new" FTC followed and extended the Morton Salt rule. The Commission held that in industries working on low profit margins, even small differentials were competitively significant enough to raise a rebuttable presumption of illegal injury. ${ }^{213}$ And the presumption was not rebutted by testimony of disfavored customers that there had been no actual injury because, by the nature of the market involved, their ability to compete on equal terms was necessarily prejudiced. ${ }^{214}$

The FTC has stated, however, that different considerations are brought into play when a seller sets significantly different prices to customers who do not compete with each other. The price differences are still "discriminations" within the meaning of the Act, ${ }^{215}$ but the injury, if any, will be in the

against the weight of authority, and in conflict with the Supreme Court's Morton Salt decision. See Justice Black's dissent from the Court's denial of certiorari on procedural grounds. Id. at 344 U.S. 206. See note 217 infra.

212. Whitaker Cable Corp., Docket No. 5722, 3 CCH Trade REg. Rep. If 25443 (FTC May 1955) ; Moog Industries, Inc., Docket No. 5723, 3 id. $\| 25444$ (FTC May 1955) ; E. Edelman \& Co., Docket No. 5770, 3 id. $\uparrow 25445$ (FTC May 1955) ; Niehoff \& Co., Docket No. 5768, 3 id. $\Uparrow 25467$ (FTC May 1955). The cases are quite similar and, for convenience, future references shall be made to the Whitaker case, which is representative.

213. Respondent had given its customers quantity discounts based upon total net purchases of its automotive parts. The discounts were progressive, and large volume customers had received substantially lower prices than smaller competitors. Whitaker Cable Corp., supra note 212, at pp. 35546-49. The FTC thought that since the profit margins in the industry were small, "Any savings or advantage in price obtained by one competitor, as against another increases his margin of profit, permits additional services to be extended to customers. . . ." Id. at p. 35549 .

214. The industry was following a system of retail price maintenance, so that customers getting lower prices were unable to undersell their competitors. Thus, disfavored customers testified that they had not actually been injured. Ibid. But the Commission held that only a likelihood of injury was necessary to proscribe the discriminations, and it found that likelihood in the narrowed margins of profit the lower volume customers had to face. Ibid.

215. Originally, $\$ 2$ was aimed at preventing manufacturers from gaining monopolies by means of local price-cutting. See H.R. REP. No. 627, 63d Cong., 2d Sess. 8 (1914). But this practice fell into desuetude after 1914. See CLARK, Economics of OverHEAD Costs 424 (1923) ; Watkins, Public Regulation of Competitive Practices in BusiNESS ENTERPRISE 66-68 (3d ed. 1940). The Robinson-Patman amendment was aimed at a different problem. See note 201 supra. But it did include inter-market discriminations within its proscriptions. See statement of Congressman Utterback, 80 CoNG. REC. 9416 (1936) ; statement of Senator Logan, 80 id. at 31.13. But see PAman, The Roninson-PATMAN ACT 50-58 (1938), stating that if the sale is at more than cost and without predatory intent the Act does not apply. The latter is not legislative history, of course. And the weight of authority precludes any argument that inter-market discrimination may not be illegal. See citation of authority in Purex Corp., Docket No. 6008, unreported initial decision, April 16,1954, at 6, 14, "finalized" by Commission failure to review, $3 \mathrm{CCH}$ Trade Reg. ReP. ff 25172 (FTC Sept. 27, 1954).

"Territorial" price discrimination may, of course, occur between markets that are separated functionally rather than geographically. See Evwards, op. cit. supra note 71, at 159 ; cf. the Spark Plug cases, Docket Nos. 3977, 5620, 5624, 3 CCH TRAdE REg. Rep. If 11467 (FTC July 10, 1953). 
primary-rather than the secondary-line. ${ }^{216}$ And in these cases the FTC will not follow the presumptions that the Supreme Court established in Morton Salt; it will require more economic evidence and a more rigorous standard of proof before inferring a likelihood of competitive injury. ${ }^{217}$

\section{Territorial Price Discrimination: The General Foods Case}

The most important primary-line decision of the "new" FTC is General Foods Corp. ${ }^{218}$ In 1939 General Foods dominated the market for pectin products, but its patents on liquid pectin had expired and its market share began to decline. ${ }^{219}$ Therefore, in 1940 it began to give "deals" whereby con-

216. Injury in the primary-line is to competing sellers rather than to customers. These sellers need not sell goods of like grade and quality so long as they are trying to get to the same general class of customers. See E. B. Muller \& Co. v. FTC, 142 F.2d 511 (6th Cir. 1944); McWhirter v. Monroe Calculating Mach. Co., 76 F. Supp. 456, 461 (W.D. Mo. 1948); Comment, 49 Nw. U.L. Rev. 209, 211 (1954). But see Midland Oil Co. v. Sinclair Refining Co., 41 F. Supp. 436, 438 (N.D. I1l. 1941).

217. See General Foods Corp., Docket No. 5675, 3 CCH Trade Reg. Rep. If 25069 (FTC April 27, 1954) ; Purex Corp., Docket No. 6008, unreported initial decision, April 16, 1954, "finalized" by Commission failure to review, 3 id. If 25172 (FTC Sept. 27, 1954); Spark Plug cases, Docket Nos. 3977, 5620, 5624, 3 id. T 11647 (FTC July 10, 1953). See notes 222-27 infra and accompanying text.

In General Foods Corp., supra, the FTC stated: "The standard for determining the unlawfulness of an unjustified price discrimination ... is the same whether the competitive injury occurs at the seller level or at the customer level." But it concluded, relying on a 1948 FTC Statement of Policy referring to the different problem of basing point selling, that the Supreme Court's decision in Morton Salt "could not automatically be applied in cases of territorial price discrimination"; more evidence of competitive effects would be required. 3 id. \25069, at 35211 (FTC April 27, 1954).

The Supreme Court apparently took the opposite position in the Morton Salt case, although in dictum. It approved S. Moss, Inc. v. FTC, 148 F.2d 378, 379 (2d Cir.), cert. denicd, 326 U.S. 734 (1945), which stated that the fact of discrimination was grounds for a prima facie inference of competitive injury in the primary-line. See Morton Salt Co. v. FTC, 334 U.S. 37, 45 n.13 (1948). See also Standard Brands, Inc. v. FTC, 189 F.2d 510, 515 (2d Cir. 1951), reaffirming Moss in light of the Supreme Court approval.

The "new" FTC does not approve of the Moss case, however, and has indicated that it will not follow it. See General Foods Corp., supra, at pp. 35212-13; note 284 infra.

218. General Foods Corp., Docket No. 5675, 3 CCH TRADE REg. REP. If 25069 (FTC April 27, 1954).

219. In 1939 General Foods sold to $75-80 \%$ of the national market and $50 \%$ of the western market for liquid pectin. Id. at p. 35210. Moreover, it sold to $40 \%$ of the national market and to $25 \%$ of the western market for powdered pectin. Ibid. General Foods thought that the western market accounted for $25 \%$ of its total pectin sales. See letter from Mr. J. Axrelrod, Products Manager, to Mrs. Myers, President, Nov. 11, 1942, Commission Exhibit 28B in General Foods Record.

In 1939 and 1940, after the patent on liquid pectin expired, General Foods lost heavily to Mutual Citrus Products (MCP), a west coast competitor. General Foods Corp., supra note 218. In the Pacific Northwest its market shares for liquid and powdered pectin dropped $8.7 \%$ and $5.6 \%$ in 1939 ; in the Southwest, the drop was only $2 \%$ and $2.8 \%$ respectively. Commission Exhibit 21. This exhibit is based upon data compiled for General Foods by a commercial surveying company. See notes 228-34 infra. 
sumers in the western market got a "free" package with every two packages they bought.220 But it did not make the same deal available to consumers in other markets. ${ }^{221}$ The sole question was whether the deals were likely to injure competition between General Foods and sellers competing with it in the western market.

The FTC held that counsel had failed to establish a probability of competitive injury. Evidence that General Foods' sales and market shares had shot up, ${ }^{222}$ and testimony by competing sellers that they had in fact been injured, ${ }^{223}$ was not thought persuasive. For during the "deal" period there had been active and virile price competition, competitors' sales had increased appreciably and competitor's prices had been generally less than the "deal" price. ${ }^{224}$ The

220. General Foods Corp., Docket No. 5675, 3 CCH Trade Reg. Rep. $\Uparrow 25069$ (FTC April 27, 1954). The "deal" cases came to grocers in sets of three; a customer could get all three packages for the regular price of two. See Initial Decision, General Foods Corp., Docket No. 5675 (August 1952), at 1. Thus, in 1946, the last year of the deal, General Foods was selling a case of Certo (its liquid pectin) for $\$ 3.18$ in the western markets; in other markets the same case cost $\$ 4.30$. And Sure-Jell, its powdered pectin, was going at $\$ 2.57$, as against an ordinary price of $\$ 3.18$. Ibid. See Commission Exhibit 99 . See note 241 infra.

221. General Foods Corp., Docket No. 5675, 3 CCH Trade Reg. Rep. $\int 25069$ (FTC April 27, 1954). Mr. Axelrod explained to Mrs. Myers that the "deal" should be used in the Pacific states because an outright price reduction would "inevitably force us to reduce the price nationally." Commission Exhibit 21, 22.

222. In 1940 General Foods gave deals on Sure-Jell and gained back ground it had lost to MCP the previous year. See note 219 supra. However, it gave no deals on Certo and lost further ground to MCP. In 1941 it gave deals on both products and gained substantially on both. Letter from Mr. Axelrod to Mrs. Myers, Nov. 1942, Commission Exhibit $28 \mathrm{~B}-\mathrm{C}$ in General Foods Record. The hearing examiner found as a fact that "the deal was advantageous to respondent, enabling it to increase its sales and improve its competitive position in that territory." Initial Decision, Docket No. 5675 (August 1952), at 4. The FTC's decision ignored these facts and findings. See notes 228-34 infra and accompanying text.

223. This testimony came primarily from $\mathrm{Mr}$. H. Leo, President of the competing MCP company. General Foods Corp., Docket No. 5675, 3 CCH Trade REg. REp. If 25069 (FTC April 27, 1954). See General Foods Record at pp. 307, 536.

Typical of the type of injury alleged is the situation in 1947, after General Foods had temporarily abandoned the deals. MCP announced a $10 \%$ price increase to meet rising costs. General Foods then announced that it would resume the deals. Its price would have undercut MCP at that point, so MCP decided not to raise prices after all. See Commission Exhibits 91-93.

The FTC was more impressed with the fact that MCP's volume of business had increased. See note 224 infra. But its margin of profit had been cut; and General Foods' volume increased more. See note 241 infra. More significant, perhaps, is the fact that MCP's volume of sales increased still more, despite a rise in price, after the deals were discontinued. Record at p. 536.

224. General Foods Corp., Docket No. 5675, 3 CCH Trade Reg. Rep. ff 25069 (FTC April 27, 1954). The FTC seems to have adopted the standards used by the Seventh Circuit in Minneapolis-Honeywell Regulator Co. v. FTC, 191. F.2d 786, 790 (7th Cir. 1951), cert. denied for lateness in filing, 344 U.S. 206 (1952) : that competition was keen in the seller's line; the discriminating seller did not undersell his competitors; the competitors' 
FTC did not think a showing of injury to competition "in general was indispensable," but it did think it necessary to consider "all the competent and relevant evidence and inferences." 225 Only evidence of a predatory intent to eliminate competitors would be sufficient to indicate competitive injury per se. ${ }^{22}$ In the absence of such evidence the Commission felt it would have to balance evidence of 1) whether there was vigorous price competition between the discriminating seller and his competitors; 2) whether the discriminatory prices were higher or lower than competitors'; and 3) whether the discriminating seller increased his sales and his market shares at the expense of his competitors. ${ }^{227}$

The majority opinion did not consider significant evidence contained in the record and pointed out in the dissent. ${ }^{228}$ Inter-office memoranda taken from General Foods' files made it clear that the intent and effect of the deals was to keep west coast competitors from expanding into General Foods' lucrative midwest markets. ${ }^{20}$ It is not possible to determine whether the FTC did not

volume of sales increased, and the discriminating seller's market share shrank. However, it failed to find evidence of market shares. See notes $228-34$ infra and accompanying text. For a critique of the Honeyzull standard, see notes 211 stipra, 241-46 infra and accompanying text.

The hearing examiner had found that there was vigorous competition in the western market, and that the vigorous competitive battle General Foods' deals forced MCP to wage "may have" stimulated total consumer demand. Initial Decision at 7 . He thought the deals were a "troublesome problem" to competitors, but that they met it with competition, and that the competition in the area was thereby "helped rather than injured." Id. at 7. And he found that MCP's sales increased up to $300 \%$, so that in 1947 it outsold General Foods by 45,000 dozen packages. Id, at 4 .

225. Id. at 6 . The FTC thought that the considerations listed in note 224 stipra, must all be examined before inferring injury in the primary line. General Foods Corp., Docket No. 5675, 3 CCH Trane Reg. Rep. If 25069 (FTC April 27, 1954). It is not necessary to examine these factors in cases of secondary-line injury, see notes 211-14 supra and accompanying text, but the Commission thought that the inferences permissible from secondary-line discrimination "could not automatically be applied" in cases of territorial price discriminations. General Foods Corp., supra. However, the distinction the FTC drew between inter-market and intra-market discriminations was founded upon a 1948 Statement of Policy that dealt with territorial discrimination as it occurs in connection with basing point delivered pricing. Ibid. There was no attempt to discover whether similar considerations apply when the discrimination is used not to prevent price competition, as in basing point systems, but to wage selective price competition.

226. Ibid.

227. See note 224 supra.

228. The materials discussed notes $229-31$ infra and accompanying text, were pointed out by Commissioner Mead in dissent. General Foods Corp., Docket No. 5675, 3 CCH TRAdE REg. REp. If 25069 (FTC April 27, 1954). The Commission found it unnecessary to mention them.

229. In December 1939, Mr. Axelrod, Products Manager, informed Mrs. Myers, President, that the growth and spread of west coast competition was becoming a threat to General Foods. Commission Exhibit 20. The next year the deals began. See note 220 silpra.

In December 1941, Mr. Axelrod reported on the progress of the deals. Although there was an operating loss on Sure-Jell because of the deals, he felt this was an "investment" 
consider this evidence because it was thought unreliable, or because it thought an intent to restrain the growth of competition is something less than an illegal intent to destroy competition. Moreover, although the Commission noted that General Foods' market position had shot up from 62 to 80 per cent of the national market during the "deal" years, it stated that statistics showing its position in the western markets were not "available." 230 Yet statistics in the record, taken from General Foods' own files, showed that its market shares had increased from 46 and 56 per cent to 62 and 69 per cent of the Pacific northwest and southwest markets respectively during the first four years of the deals. ${ }^{231}$ The FTC did not mention these figures, nor did it indicate why they were not "available."

In other cases the "new" Commission has recognized that statistical data taken from a respondent's files have great probative value. ${ }^{232}$ Even if they are inaccurate representations of market realities, they are very accurate indications of what respondent thought those realities were. Robinson-Patman is framed in terms of probable effect, ${ }^{233}$ but evidence of purpose delineates

in future profits. And apparently he thought it was a successful investment, because by 1941 respondent had "almost doubled our Sure-Jell business and at the same time stopped the decline on Certo." See Commission Exhibit 27.

In November 1942, Mr. Axelrod stated that, had the deals not made it "tough" for MCP, they "would have spread eastward at a much faster rate than they did and we would now be facing some pretty tough competition in the middle-west. . . the high SureJell per capita market." "If we can, by means of this deal operation, confine this competition largely to the far west, I think it is good insurance and that the deal serves a twofold purpose." Commission Exhibit 28D.

230. General Foods Corp., Docket No. 5675, 3 CCH Trade REg. Rep. If 25069, at p. 35213 (FTC April 27, 1954). The Commission apparently took these figures from the hearing examiner, see Initial Decision at 3, who derived them from the same source as the figures for the western market, see note 231 infra, that the Commission found were not "available."

231. General Foods gauged the success of its deal operations from market surveys made for it by the Nielsen Company. See Commission Exhibit 19 . These reports revealed:

\begin{tabular}{llllll} 
& \multicolumn{5}{c}{ PACIFIC NORTHWEST } \\
General Foods & $54.5 \%$ & $46.1 \%$ & $59.1 \%$ & $56.9 \%$ & $62.5 \%$ \\
MCP & - & - & - & 13.0 & 15.7 \\
All other competitors & 45.5 & 53.9 & 40.9 & 30.9 & 21.8 \\
YEAR & 1938 & 1939 & 1940 & 1941. & 1942 \\
& \multicolumn{5}{c}{ PACIFIC Southwest } \\
General Foods & 69.9 & 55.7 & 52.0 & 68.2 & 69.1 \\
MCP & - & - & - & 17.7 & 19.9 \\
All others & 27.1 & 44.3 & 48.0 & 14.1 & 11.0
\end{tabular}

See Commission Exhibit 28C, 29C in General Foods Record.

232. See Pillsbury Mills, Inc., Docket No. 6000, 3 CCH TRAde Reg. Rep. I 11582 (FTC Dec. 28, 1953) ; Crown Zellerbach Corp., Docket No. 6180, 3 id. If 25458 (FTC May 1955).

233. See S. Doc. No. 584, 63d Cong., 2d Sess. 4 (1914) ; S. Doc. No. 585, 63d Cong., 2d Sess. 3 (1914); text at note 201 supra. 
the nature of the act and also sheds light on future competitive probabilities..$^{234}$ For a seller may discriminate between different markets in order to compete in both; but he may also discriminate to suppress competition, to contain competition, or to coerce rivals into following his leadership. ${ }^{235}$ RobinsonPatman does not in terms distinguish between the two instances, ${ }^{236}$ but evidence showing the seller's intent is certainly relevant in gauging the probable effects of his pricing. For whenever a sizable seller's purpose in discriminating is to suppress or contain or coerce competitors it is probable that he "may" succeed. ${ }^{237}$ Businessmen ordinarily do not follow commercial policies that are not likely to succeed; they should have the burden of proving their lack of "reasonable business judgment" once their intent is shown.

Direct evidence of intent should not be necessary. ${ }^{238}$ Certain types of conduct should constitute circumstantial evidence of intent. Selling below cost indicates an intent to injure competition. ${ }^{230}$ The closer the price comes to cost, the more readily intent may be inferred. Other significant factors bearing upon intent include the length and severity of the price cut; the size and strength of the seller in all the markets he sells in; and, inevitably, his previous anti-competitive record. ${ }^{240}$

The decision in General Foods would be erroneous even if there had been no intent to injure competition. The FTC's finding that General Foods' deal prices were generally higher than competitors' ignores the fact that General Foods was selling a premium, nationally advertised product. ${ }^{241}$ The finding

234. "[K]nowledge of actual intent is an aid in the interpretation of facts and prediction of consequences." Appalachian Coals, Inc. v. United States, 288 U.S. 344, 372 (1933) ; see E. B. Muller \& Co. v. FTC, 142 F.2d 511, 517 (6th Cir. 1944). The test of intent is "not a test of the purity of a company's motives, but an evaluation of its conduct." Dirlam \& KaHN, op. cit. supra note 3, at 65 . See also Kahn, $A$ Legal and Economic Appraisal of the New Sherman and Clayton Acts, 63 YALE L.J. 293, 317 (1954).

235. See ClarK, op. cit. supra note 215, at 424; EDWARDs, op. cit. supra note 71, at 159. Territorial discrimination is probably used more to discipline non-conformists than to eliminate them. Therefore it is not necessary to cut the price so deeply or maintain it so long.

236. See note 234 supra.

237. See Adams, The "Rule of Reason": Workable Competition or Workable Manopoly?, 63 YALE L.J. 348, 359 (1954).

238. See Comment, 49 Nw. U.L. Rev. 209, 216 (1954); American Tobacco Co. v. United States, 328 U.S. 781, 809 (1949) (conspiracy); Allied Paper Mills v. FTC, 168 F.2d 600, 607 (7th Cir. 1948) (same).

239. Porto Rican Am. Tobacco Co. v. American Tobacco Co., 30 F.2d 234 (2d Cir. 1929); E. B. Muller \& Co. v. FTC, 142 F.2d 511 (6th Cir. 1944); Simon, Geographic Parcing 302 (1950). General Foods' prices were, at times, below operating costs. See note 229 supra; cf. notes $246-56$ infra and accompanying text.

240. See Comment, 49 Nw. U.L. Rev. 209, 216 (1954). On the importance of an anticompetitive record see DIRLAM \& KaHn, op. cit. supra note 3, at 104; EDwards, op. cit. supra note 71, at 159, 160-67; United States v. Swift \& Co., 286 U.S. 106, 116 (1932).

241. General Foods' national reputation and its patent monopoly on liquid pectin prior to 1939 , see note 219 supra, certainly put it in a premium position over the newcomer MCP, cf. note 231 supra. Yet in 1947 , when MCP was selling at $\$ 2.55$ per case, General Foods' 
that some competitors were still able to compete with it despite the discriminatory pricing would seem to be irrelevant. ${ }^{242}$ Their ability to compete equally is belied by the large market gains General Foods made at their expense. ${ }^{243}$ But evidence of those gains should also be unnecessary in order to establish a prima facie case of competitive injury. ${ }^{244}$ By requiring such evidence the FTC would obliterate the distinction Congress drew between injury to competition and injury to competition with the person benefiting from the discrimination in price. For the purpose of the Robinson-Patman Act was to prevent price discriminations from lessening the ability of any businessman to compete on equal terms with any of his competitors. ${ }^{245}$

\section{Territorial Price Discrinination: An Economic Appraisal}

Territorial price discrimination enables firms with monopolistic leverage in non-competitive "home" markets to tie that leverage to the economies of size. ${ }^{243}$

Sure-Jell (regularly selling at $\$ 3.18$ per case) was given at a deal price of $\$ 2.57$. See note 220 supra; Commission Exhibits 99, 103-07, 110-11, 122-23 in General Foods Record. This margin is hardly sufficient to cover the gap of national advertising and prestige reflected in General Foods' normal selling price. See Austin, op. cit. supra note 206, at 46; cf. Howrey, Statement Before the Subcommittee on Antitrust of the House Committee on the Judiciary 15 (1955) (mimeograph).

242. See notes 125-30 supra and accompanying text. A showing of workable competition despite the use of discriminatory pricing would be even less relevant under the standard of Robinson-Patman than it is under other sections of the Clayton Act. See note 201 supra. Moreover, there was no showing of "workable" competition in General Foods. As a result of the discrimination only one competitor, $M C P$, was able effectively to offer competition to General Foods. Other competitors lost heavily. See note 231 supra; General Foods Corp., Docket No. 5675, 3 CCH TrADE REg. REp. If 25069 (FTC April 1954). This step towards duopoly in the market would tend to outweigh the "vigor" of competition between General Foods and MCP. See note 224 supra. And the low-profit price competition would be apt to discourage new entrants.

243. See note 231 supra.

244. See notes 201,206 supra, 246-82 infra and accompanying text. If a leading seller uses a discriminatory price structure to disadvantage his competitors, that should suffice to establish a prima facie case that he has injured competition between them and himself. It may be that this resulted in his failure to lose as much ground to them as he ordinarily would have done.

245. The "competition with" language was added to the statute to alleviate difficulties of proof and to prevent larger sellers from putting their competitors or any of them at a substantially disadvantageous position by means of discriminatory selling. See S. REP. No. 1502, 74th Cong., 2d Sess. 4 (1936) ; H.R. REP. No. 2287, 74th Cong., 2d Sess. 8 (1936); Statement of Congressman Patman, 80 CoNG. Rec. 81.11 (1936) ; Statement of Congressman Utterback, 80 id. at 9417; AUSTIN, op. cit. supra note 206, at 42; EDWARDs, op. cit. supra note 71, at 167; Comment, 49 Nw. U.L. REv. 209, 213 (1954); Note, 36 CoLUM. L. Rev. 1285, 1287, 1296 (1936). But see Note, 55 Colum. L. Rev. 106, 108 (1955).

246. See notes 249-61. infra and accompanying text. Systematic price discrimination between markets is not profitable unless there is a substantial degree of control in the home market. See CLARK, op. cit. supra note 215, at 416-33; BuRNs, op. cit. supra note 173, at 273-74; Fetter, The Masquerade of Monopoly 335, 382 (1931). Unless the discriminating seller is a monopolist or oligopolist, it would be more profitable for him to lower the price and get more business in the "home" market. 
The discriminating seller is able to utilize excess capacity (at diminishing costs) by reaching into new markets rather than "spoiling" his market at home $;^{247}$ this in turn permits him to compete in the outlying market with distinct advantages over local sellers. ${ }^{248}$

Territorial discrimination is not possible unless the seller is able to insulate the buyers in different markets. ${ }^{240}$ It is not profitable unless he has fixed costs and excess capacity ${ }^{250}$ and unless there are strong elements of monopoly in his home narket. ${ }^{251}$ But in this sense national or regional advertising which creates consumer demand for a trade-named product is the same as an idle fixed cost item: it creates an extra capacity to sell the product in other markets that is useless in the home market, but that can be utilized in other markets without further outlay. ${ }^{252}$ When these conditions exist, territorial discrimination enables the national or regional seller to fortify his monopolistic

247. See notes 254-56 infra and accompanying text.

248. See notes $257-60$ inf $r a$ and accompanying text.

249. A discrimination must not be great enough to permit the recipient to engage in arbitrage transactions. If the recipient can re-sell to the seller's disfavored customers at less than the seller himself is currently charging them, the advantages of discriminating are nullified. However, deeper price slashes are feasible in an inter-market than an intramarket discrimination, because there is less opportunity for arbitrage. See Boulding, EConomic ANalysis 533, 538 (1948) ; ClaRK, op. cit. supra note 215, at 419-20; Rowe, silpra note 201, at 936.

250. If a firm is already producing at capacity (i.e., its most efficient point of production), the added cost of each added unit it produces thereafter will exceed the added cost of each previous unit and will also exceed its own average cost. See Bouldivg, op. cit. stupra note 249, at 563-67; Stigler, op. cit. supra note 71, at 170; Machlup, Marginal Analysis and Empirical Research, 36 Axr. Econ. Rev. 519, 523 (1946). This would not necessarily make discrimination unprofitable, but it would strongly tend to do so.

251. See note 246 supra.

252. It is more usual to view advertising as a variable cost of selling rather than a fixed expense. If advertising expenditures are successful, they will increase the demand for the seller's product (make his demand curve more "horizontal"). This will generally make it more profitable to produce a greater number of units, which would seem to lessen excess capacity. However, "selling costs per unit are greater than the decrease in production costs. The resources expended to achieve this result are therefore greater than those saved by achieving it. And, of course, the balance of excess capacity remains." Chantrerlin, op. cit. supra note 49 , at 172 ; see id. at 163-76.

Moreover, advertising outlays often are fixed at a "normal" level by trade practice or inertia. Id. at 143. Mass national or regional advertising media such as radio and television may serve communities the seller does not already sell to as well as those to which he does. The cost is fixed as part of his sales expense in communities he sells to; the excess spills over into other communities, ready for exploitation. In so far as this advertising creates a demand for a trade-named product among buyers that are not currently served, the excess seems functionally equivalent to the excess of plant capacity that makes discrimination profitable.

Finally, large advertising outlays tend to prevent entry by newer firms. See American Tobacco Co. v. United States, 328 U.S. 781, 797 (1946); CEAMrBerLin, op. cit. supra, at 173; cf. Spark Plug cases, Docket Nos. 3977, 5620, 5624, 3 CCH TraDE REg. REP. $\mid 11467$ (FTC July 1953). 
position in his home market and gives him a head start towards establishing one in the new market. ${ }^{253}$

When a regional seller expands into or expands within an outlying market. his profit in that market is based upon the added cost of the added units he sells there..$^{254}$ So long as he has fixed costs and capacity to produce more than he can sell without lowering the price in the home market, the added cost of each added unit will be less than the cost of the units sold in the home market, and less than its own average cost. ${ }^{255}$ The fixed expenses have already been allocated to the cost of the units sold in the home market. ${ }^{256}$

These cost savings give the regional seller a substantial advantage over local sellers. He can profitably divert trade from local sellers by selling at less than average cost. ${ }^{257} \mathrm{He}$ can sell his product at a lower price in the outlying market and still match the profit he makes on equivalent units sold at higher price in the home market. ${ }^{258}$ The price in the outlying market is "sub-

253. See notes 254-65 infra and accompanying text. It is the joint effect as well as the several that makes territorial discrimination dangerous. Its effects are similar to a tying contract in that it is anti-competitive in both its markets. The discussion infra centers upon the effect upon outlying markets through lowered marginal costs. However, as the seller increases his output towards capacity, his average costs also drop. See CLARK, op. cit. supra note 215 , at 420 ; BuRns, op. cit. supra note 173 , at 329 ; STIGLER, op. cit. supra note 71 , at 170 . This permits the seller to entrench his position at home, which is already monopolistic. See note 246 supra. And that will further intensify the effect upon outlying markets. Cf. the Spark Plug cases, supra note 252 . It will seriously impede entry in either market. See ibid.; note 276 infra.

254. Burns, op. cit. supra note 173, at 273; Machlup, The Economics of Selier's COMPETITION 543 (1952) ; STIGLER, op. cit. supra note 71, at 216-17. So long as the markets are separated, the seller can slash prices in the local market without fear of repercussions in the other. See note 249 supra. So long as his home profit is secure, whatever he realizes from the new market above the out-of-pocket expenses he incurs is an added profit to him. See Clemens, Price Discrimination in Decreasing Cast Industries, 31 Anr. EcoN. Rev. 794 (Supp. 1941).

255. See Burns, op. cit. supra note 173 , at 329 ; Boulding, op. cit. supra note 249 , at 463-67; CIARK, op. cit. sutpra note 215, at 420; Adelman, Integration and Public Policy, 63 HARv. L. Rev. 27, 39 (1949). In actual markets, where products are differentiated and advertised, and a seller cannot sell as much as he can produce at a given market price that is the same for all sellers, firms inevitably maximize their profits by producing below the point of most efficient (capacity) output. See Bourding, op. cit. supra, at 577; CerassBERLIN, op. cit. supra note 49 , at 88.

256. "Discrimination is practiced because it increases the amount of the product over which the overhead is spread; that is, the fixed expenses have already been incurred, and it costs only the additional variable cost to obtain the additional product. Since the increment to output is thus procured at less than its total cost ... it can be sold at less than its total cost, and yet add to profits." Adelman, supra note 255, at 40; CLARK, op. cit. supra note 215 , at 416 .

257. The regional seller will try to price his product as closely as possible to his competitors' prices. See BouldrNG, op. cit. supra note 249 , at $574-75$ (theory of "minimum differentiation"). Because he can afford to work on any excess over marginal costs in the local market, see notes 254-56 supra and accompanying text, he can sell at a lower price than if he had to figure his profits on the basis of average costs. See note 258 infra.

258. So long as his price exceeds his marginal costs by the same amount in each 
sidized" because buyers in the home market are paying more than their share of the fixed costs. ${ }^{250}$ The price may be further subsidized because the regional seller can "average out" lower profits in the outlying market with higher profits he is able to maintain in a less competitive home market:260 any extra profit he can make without spoiling his home market is welcome. ${ }^{261}$

The local seller is put at a substantial disadvantage. When a regional seller enters his market with an advertised product and competes for his customers, the local seller must lower his price or lose customers. ${ }^{262}$ This may temporarily increase competition in the local market. ${ }^{263}$ But it is the low price alone that increases competition. ${ }^{204}$ No one objects to the low price alone; it is the discriminatory combination of a low subsidized price in the local market tied to a higher price in the monopolistic home market that is objectionable. ${ }^{265}$ For when a local seller lowers his price he must lower his profit margin; he cannot make it up elsewhere. This puts the local seller in the same position as a small buyer trying to compete with a larger firm that is able to coerce a discriminatory discount from a common supplier. ${ }^{206}$ He cannot compete on equal

market, his profits are the same. See Burns, op. cit. supra note 173, at 329; ChamberLin, op. cit. supra note 49 , at 76-78.

259. See notes 254-56 supra and accompanying text. In the secondary-line it is illegal to charge some customers lower prices based upon the marginal cost of selling to them rather than the average cost of selling to all customers. See S. REP. No. 1502, 74th Cong., 2d Sess. 5 (1936) ; H.R. REP. No. 2287, 74th Cong., 2d Sess. 10 (1936) ; statement of Congressman Utterback, So Cong. Rec. 9417 (1936); Patman, op. cit. supra note 215, at 19-20. This should hold true with respect to the primary-line as well.

260. It is clear that a seller seldom "recoups" local losses by raising prices elsewhere; he is probably charging all he can get to start with. See Rowe, supra note 201, at 937. But see statement of Senator Logan, 80 CoNG. Rec. 3113 (1936). However, so long as his profits are secure in the home market, he "can afford to enter his rival's territory and sell an additional lot of goods there for less than he can afford to take as an average on his whole output..." ClaRK, op. cit. supra note 215, at 420; see DIRLAM \& KaHN, op. cit. supra note 3 , at 208 . Furthermore, he may be willing to forego immediate profits in anticipation of future monopoly profits. See id. at 144-50; Boulding, op. cit. sutpra note 249 , at 56061 ; Rowe, supra, at 937. This, apparently, was General Foods' motive. See note 229 supra.

261. The reason that the seller is willing to "average out" higher profits with lower, see note 260 supra, is that in reality it is not an averaging at all. The profit in the new local market may be at a lower rate than profits in the home market, but it is extra profit. And, more important, if the seller is unable to sell more units in the home market without lowering the price on all his units, the "average" is likely to be higher than if he sold the extra units in the home market and had to sell all units at a lower price.

262. See note 257 supra.

263. The entry of a regional seller will, of course, make the local sellers compete vigorously for the business in the market. See Simon, op. cit. supra note 239, at 302; Rowe, supra note 201, at 937. But the gain usually is only temporary. See PatMan, op. iit. supra note 215 , at 35 .

264. See Note, 55 Colum. L. Rev. 106, 108 (1955).

265. See notes 254-61 supra and accompanying text. The economic advantages inherent in a discriminatory price structure stack all the cards in favor of the discriminating seller. And territorial discriminations "have little value in developing new business. They serve chiefly to determine which competitor shall secure the larger share of the existing business." Clakr, op. cit. supra note 215 , at 425 .

266. See DirLam \& KAHN, op. cit. supra note 3, at 208-09. 
terms because of the combined effects of the economies of size and the imperfection of markets, and the use of discriminatory pricing as a lever. ${ }^{267}$ There is every likelihood that competition between him and the regional seller will be injured. Furthermore, competition may be injured between the regional seller and his competitors in his home market. ${ }^{268}$

Imperfect competition is a fact of life; it cannot be avoided. ${ }^{260}$ Methods which accentuate and entrench imperfect competition can be prevented. Congress singled out several of these methods in the Clayton Act. ${ }^{270}$ One was price discrimination. ${ }^{271}$ The potentiality of harm from price discrimination was so great that Congress amended the Clayton Act to require not the Clayton Act standard of probable injury to competition but the less demanding Robinson-Patman standard of probable injury to competition with any person granting or receiving the benefit of a discrimination. ${ }^{272}$ This change was directed towards injury at the secondary-line, but it was not limited to it. ${ }^{273}$

Whenever a sizable firm sells a nationally or regionally advertised product at a discriminatorily low price in an outlying market in which it does a sizeable volume of business, the FTC should find a prima facie likelihood of injury to competition between that seller and his competitors in the local market. The discrimination gives the regional firm too great an opportunity to use market power to eliminate or cow rivals $;{ }^{274}$ it puts local sellers at too great a disadvantage $;^{275}$ and it provides too economical a way to block entry in both markets. ${ }^{276}$ It is the policy of Robinson-Patman to prevent these abuses before they can materialize; evidence that they have not yet occurred would seem irrelevant. ${ }^{277}$

267. Ibid.

268. See note 253 supra. The natural tendency of a territorially discriminatory price structure is to strengthen the monopolistic seller in his own home market. This will tend to injure competition between him and his smaller competitors in that market. Legal thought has apparently neglected this form of competitive injury, which might well make the use of territorial discrimination illegal as such when used by a substantial seller.

269. See, e.g., DirLam \& KAHN, op. cit. supra note 3, at 147; Hale \& Hale, Markot Imperfections: Enforcement of the Antitrust Laws in a Friction-Aflicted Economy, 102 U. PA. L. REv. 157, 159-68 (1953). Principal imperfections are consumer ignorance (aided by advertising), immobility, space and time lag, inertia, differentiation and governmental action. Ibid. Adelman, supra note 255 , at 39 .

270. 38 Stat. 730 (1914), as amended, 15 U.S.C. $\$ \$ 12-27$ (1952). See Times-Picayune Publishing Co. v. United States, 345 U.S. 594, 609-10 (1953) ; Standard Oil Co. v. United States, 337 U.S. 293, 311-13 (1949); DrRLAMr \& KAHN, op. cit. supra note 3, at 48.

271. 38 Stat. 730 (1914).

272. 49 Stat. 1526 (1936), 15 U.S.C. $\$ 13$ (1952). See notes 206, 245 supra and accompanying text.

273. See note 215 supra.

274. See notes 254-61 supra and accompanying text; note 235 supra.

275. See notes $262-68$ supra and accompanying text.

276. See Landon, Geographic Price Structures, 15 Law \& Contear. Prob. 125, 126 (1950) ; Kahn, A Legal and Economic Appraisal of the "New" Sherman and Clayton Acts, 63 Yale L.J. 293, 340-41 (1954); notes 253, 268 supra; cf. the Spark Phig cases, Docket Nos. 3977, 5620, 5624, 3 CCH TrAde Reg. Rep. I 11467 (FTC July 1953).

277. See note 201 supra and accompanying text. 
The regional or national seller should not be able to rebut the prima facie case of competitive injury thus established unless he can prove that local sellers actually had the competitive advantage. ${ }^{278}$ This would permit a cautious seller to test the response to his products in different markets before committing himself to a reduction across the boards. ${ }^{279}$ His burden of proof would not be difficult. But it would prevent a seller from using discriminatory pricing first to establish local leadership and then to raise his price. He would have to raise his price well before he became one of the leaders if he also intended to maintain his price in his home market. However, it is doubtful whether even this defense should be available to sellers who have obtained significant power in national or sizable regional markets. 280 Their market strength would establish them as threats to local sellers even before they became established in the local market.281 If they wish to expand they are free to do so-at their regular prices. They are always free to lower that price to compete. ${ }^{282}$

\section{Administrative “Expertise” and Antitrust Enforcenent: The Role of THE COURTS AND THE FTC}

The "new" Commission has asserted that its "expertise" frees it from the per se presumptions the Supreme Court established in Standard Stations. ${ }^{283}$ More-

278. Austin, op. cit. supra note 206, at 44.

279. "If a seller must by law lower all his prices or none, he will hesitate to lower any." Rowe, supra note 201, at 956. It is not the purpose of Robinson-Patman to prevent the lowering of prices; only to prevent the discriminatory lowering of some prices to some customers when that makes competitive injury likely. And a lower price in a local market which the seller is just entering, if it is maintained for only the limited period necessary to test consumer response, is likely to have a "comparatively slight" effect on competition with other sellers. See Comment, 49 Nw. U.L. Rev. 209, 220 (1954).

280. "When a giant corporation expands in its own or adjacent markets, it can hardly assert the equities of the small newcomer. ..." Schwartz, Potential Impairment of Comfetition-The Impact of Standard Oil of California v. United States on the Standard of Legality Under the Clayton Act, 98 U. PA. L. Rev. 10, 39 (1949).

281. MeRger RePoRT 103; Adams, The "Rule of Reason": Workable Competition or Worhable Monopoly?, 63 YALE L.J. 348, 367 (1954); cf. DiRLAMI \& KAEN, op. cit. supra note 3 , at 147 .

282. Robinson-Patman has been criticized for promoting "soft" competition for smaller firms by relieving them from the competitive strain of lowered competitive prices. See AtT'y Gen. Conm. Rep. 161-66; Oppenheim, Federal Autitrust Legislation: Guideposts to a Revised National Antitrust Policy, 50 MrсH. L. Rev. 1139, 1198 (1952); Simon, The Phantasy of the Phrase "Injury to Competition," 15 Law \& Contenr. Prob. 258 (1950). Eut it is not the low price that Robinson-Patman proscribes: it is the tying of an unlowered price in the home market with a lowered, subsidized price in the local market. See notes 264-65 supra and accompanying text. This permits the large firm to choose its areas of competition: to "play its area pricing pattern like a piano." See General Foods Corp., Docket No. 5675, 3 CCF TRADE REG. ReP. \ 25069, at p. 35217 (FTC April 1952) (Mead dissenting). This is very "soft" competition for the discriminating seller, and for its local competitors it is unfair competition. Ibid.

283. See notes 101-03 supra and accompanying text (IIaico case). 
over, in its territorial price discrimination cases it has stated that it will not follow Moss v. FTC, although Moss has been approved by the Supreme Court. ${ }^{284}$ These assertions of independence compel a re-examination of the function of the "expert" administrative tribunal in an effective antitrust enforcement scheme. This re-examination will center upon 1) whether there is a real need for an administrative agency in the antitrust field 2) whether the "new" FTC is filling that need 3) whether the Commission is diverging from standards established by Congress and the Supreme Court 4) whether, and to what extent, such divergence should be permitted, and 5) what curbs, if any, should be imposed upon divergence.

Certainly, there is great need for an administrative agency to assist in enforcing the antitrust laws. These laws are, in effect, a skeletal framework of terms of art which gradually acquire detailed meaning through subsequent decisions. 285 The essentially legislative nature of this process is well suited to an administrative agency, which is more frankly responsive to political changes than are the courts. Furthermore, the complexity of antitrust problems and antitrust litigation call for a body of experts who, by devoting their full time to the problems involved, can acquire a facility in the field that the judge is ordinarily unable to acquire.

All in all, the "new" Commission seems to be fulfilling its quasi-legislative, quasi-judicial functions. It has given expression to the business policies of the current political administration. It has made progress towards securing compliance with a minimum of litigation by trying to enlist the co-operation of businessmen. ${ }^{286}$ It has made excellent use of its investigative facilities to increase its "expertise."287 And it has put that "expertise" to work by adopting legal standards that turn upon market analysis.

It does appear, however, that the Commission has departed from antitrust standards established by Congress and the Supreme Court. It has concluded that its "expertise" permits and requires it to consider market evidence which -it believes-the Supreme Court has excluded under a per se rule. ${ }^{288}$ And in its territorial discrimination cases it has adopted interpretations of the law which are in conflict with the purpose of the Robinson-Patman Act, as that purpose is revealed by legislative history and Supreme Court decisions.280

These types of departures must be distinguished. The problem raised by FTC insistence upon more complete factual analysis is different from the prob-

284. The Supreme Court approved Moss v. FTC, 148 F.2d 378 (2d Cir.), ccrt. denied, 326 U.S. 734 (1945), in FTC v. Morton Salt Co., 334 U.S. 37, 45 n.13 (1948). But the FTC noted that Moss was criticized by many writers, and was contrary to congressional intent. General Foods Corp., Docket No. 5675, 3 CCH Trade REg. Rep. If 25069, at pp. 35212-13 (June 1954). See note 217 supra.

285. For an excellent discussion of this process see FTC v. Ruberoid Co., 343 U.S. 470, 486-87 (1952) (dissenting opinion of Justice Jackson).

286. See notes 30-61 supra and accompanying text.

287. See note 13 supra.

288. See notes 99, 101-103 supra and accompanying text.

289. See notes 215-82 supra and accompanying text. 
lem raised by its adoption of conflicting statutory interpretations. Administrative agencies have traditionally considered types of evidence inadmissible before the courts. ${ }^{200}$ Moreover, the FTC was created to evaluate complex factual situations $;^{201}$ it should not refrain from doing so simply because judges feel ill-suited to become embroiled in economic analysis. Fuller evaluation of marketing data may justify different conclusions as to the probable effects of competitive practices. Divergence should be permitted to the extent that it results from a fuller evaluation of relevant marketing data. The same divergence necessarily arises from court to court, varying with the acuity and experience of the judge.

Although the FTC's "expertise" gives it greater leeway in applying the law to the facts of particular cases, it should not give it license to apply a standard of legality different from that established by the Supreme Court. Dual enforcement of the antitrust laws by the courts and FTC should not lead to the enforcement of different laws. ${ }^{292}$ Thus, the Commission should not be allowed to give weight to evidence that the Court has held irrelevant as a matter of statutory interpretation. It should be reversed whenever it permits a respondent to rebut a case of competitive injury by introducing evidence of "workable competition."293 For although Standard Stations may not have established the general per se rule the FTC thinks it did, it certainly did hold that workable competition is no defense to the probable injury requirement of the Clayton Act. ${ }^{294}$ Moreover, the amounts and types of admittedly relevant evidence that the Commission requires to establish a prima facie case should not be permitted to become so disproportionate to the amounts and types required by the courts and by the statutes that they constitute, in effect, a different standard of legality. The requirement that a merger or a territorial discrimination is not illegal unless it tends to injure competition "in general" seems subject to attack on this ground. ${ }^{295}$

290. E.g., hearsay evidence is admissible before administrative tribunals. Consolidated Edison Co. v. NLRB, 305 U.S. 197, 229-30 (1938), and cases there cited; cf. also note 232 supra (admissibility of market surveys).

291. See note 10 supra and authorities there cited.

292. See Standard Oil Co. v. United States, 337 U.S. 293, 310 n.13 (1949) ; Art'y Gery. Comm. Rep. 148 n.77; of. Note, 55 Colun. L. Rev. 561 (1955).

293. See notes 125-30 supra and accompanying text. The FTC bases its ability to consider this evidence on its "expertise" and on the Supreme Court's statement in Standard Oil Co. v. United States, supra note 292, that the economic questions in that case were "most ill-suited for ascertainment by the courts," id. at 310, even if "capable of administration" by the FTC. Id. at 310 n.13.

However, the FTC took this statement out of context, for the Court went on to state that one rule would be necessary for both courts and Commission. "Our interpretation of the Act, therefore, should recognize that an appraisal of economic data which might be practicable if only the latter were faced with the task may be quite otherwise for judges unequipped for it either by experience or by the availability of skilled assistance." Ibid. (Emphasis added.)

294. See note 99 supra.

295. See notes 146-200 supra (mergers), notes 215-82 supra (territorial discriminations) and accompanying text. 
The standards of legality employed in FTC decisions should be subject to judicial review whether the Commission upholds or dismisses the complaint. All "final" orders are subject to review whether they are "positive" or "negative." ${ }^{206}$ At present, however, there is no appeal from FTC orders dismissing complaints. ${ }^{297}$ For when the FTC dismisses a complaint its counsel cannot, and respondent will not, bring the exculpatory order to the courts. And there is doubt whether anyone else has "standing" to appeal the order. ${ }^{208}$ Appellate review of future FTC negative orders may be possible without further legislative action, however. The Supreme Court has shown a marked tendency to by-pass "over-refined technique" in order to review administrative orders and has instead emphasized pragmatic effects. ${ }^{209}$ Thus, a competitor of an acquitted respondent-especially a competitor who intervened in the FTC proceedings $5^{300}$-might acquire appellate "standing" by showing that the administrative order would subject him to substantial commercial loss. He might be held to be an "aggrieved person" even though, technically, he would be unable to demonstrate the "legal injury" traditionally required for an appellate "controversy." $301 \mathrm{He}$ would be acting as a private attorney general, seeking

296. Administrative Procedure Act, 60 StAT. 237 (1946), 5 U.S.C. $\$ 1001$ (d), 1009 (c) (1952). The "negative order" doctrine, denying the reviewability of administrative orders dismissing complaints, or otherwise failing to change the status quo, was laid to rest by the Supreme Court in Rochester Tel. Corp. v. United States, 307 U.S. 125 (1939).

297. See note 23 supra and accompanying text.

298. The Administrative Procedure Act provides: "Any person suffering legal wrong because of any agency action, or adversely affected or aggrieved by such action within the meaning of any relevant statute, shall be entitled to judicial review thereof." 60 STar. 237 (1946), 5 U.S.C. $\$ 1009$ (a) (1952). However, there is some difficulty in determining who is an "aggrieved" person within the meaning of the Act. The difficulty arises because it is unclear to what extent the Act modifies the old legal doctrine that an injury to a legally protected right must be shown in order to acquire appellate "standing." See Davis, Administrative Law \$§ 199-202 (1951); Associated Industries v. Ickes, 134 F.2d 694, 700-01 (2d Cir.), dismissed as moot, 320 U.S. 707 (1943). Furthermore, appellate procedures must satisfy the requirement that there be a "case or controversy." U.S. CoNST. art. III, § 1. See Davis, op. cit. supra, § 200; Associated Industries v. Ickes, supra, at 701.

299. In Columbia Broadcasting System v. United States, 316 U.S. 407, 425 (1942), the Supreme Court stated that the real test of standing to get review "is not to be found in an over-refined technique, but in the need of the review to protect from the irreparable injury threatened. ..." It is dangerous to generalize from these cases, which are sui generis, but they do reveal that the Court will not necessarily insist on a legally protected right. It is quite possible to take these cases as granting standing to businessmen who suffer substantial commercial injury from an agency action which has the pragmatic effect of fixing their rights in relation to a respondent. See Isbrandtsen Co. v. United States, 211 F.2d 51, 56 (D.C. Cir. 1954).

300. See DAvIs, op. cit. supra note 298, $\$ 203$; cf. Administrative Procedure Act, 60 Stat. 242 (1946), 5 U.S.C. \& 1038 (1952), "Interested persons" may intervene in FTC cases. See note 16 supra. Intervention as such, however, does not give rise to appellate standing. See Perkins v. Lukens, 310 U.S. 113 (1940) ; Pittsburgh \& W.Va. Ry. v. United States, 281 U.S. 479 (1930).

301. See note 298 supra.

The competitor is not a party to the FTC action. See note 16 supra. He has no legal 
at his own cost to vindicate the public interest in a correct and uniform interpretation of the antitrust laws..$^{302}$

\section{CONCLUSION}

It would be neither fair nor accurate to conclude only that the "new" FTC has disregarded the will of Congress or the authority of the Supreme Court. In pursuing legitimate administrative functions it has rendered some decisions which are open to serious criticism. Its territorial price discrimination cases seem clearly erroneous. Maico and Pillsbury contain ambiguities that seem at odds with Congressional intent and judicial authority. However, these decisions seem best regarded as dangers inherent in an essentially desirable change in approach : a renewed emphasis on "expert" market analysis. So long as judicial review is available to insure that future decisions do not fall out of line with the substantive requirements of the law, the new directions of the new Federal Trade Commission should carry it towards improved enforcement of the antitrust laws.

right to require the FTC to proceed against respondent. That proceeding is made solely in the public interest. Ibid.

However, Davis, op. cit. supra note 298, at 715, states that it should be sufficient for the purposes of "standing" that a businessman have a substantial interest in correcting an alleged error in the administrative agency's determination; it should not be necessary for him to show injury to a "legal" right. "Instead of holding that a person with no right has standing to represent the public interest but not his own interest ... the Supreme Court should hold that a person who is adversely affected may for that reason have standing to represent his own interests, even though the public interest is the criterion for judgment." Id. at 717 .

302. Statutorily "aggrieved" persons are private litigants, but they have standing "as representatives of the public interest." Scripps-Howard Radio, Inc. v. FCC, 316 U.S. 4, 14 (1942); see FCC v. Sanders Radio Station, 309 U.S. 470,477 (1940).

Deeming the competitor to be acting as a private attorney general would seem to satisfy the constitutional requirement of an appellate "controversy." See note 298 supra. For, Congress may "authorize one of its own officials, such as the Attorney General, to bring a proceeding to prevent another official from acting in violation of his statutory powers.... Instead of designating the Attorney General . . Congress can constitutionally enact a statute conferring on any non-official person ... authority to bring [such] a suit . . . even if the sole purpose is to vindicate the public interest. Such persons, so authorized, are, so to speak, private Attorney Generals." Associated Industries v. Ickes, 134 F.2d 694, 704 (2d Cir.), dismissed as moot, 320 U.S. 707 (1943). 